UDK 902

ISSN 1330-0644

VOL 37/2020.

ZAGREB, 2020.

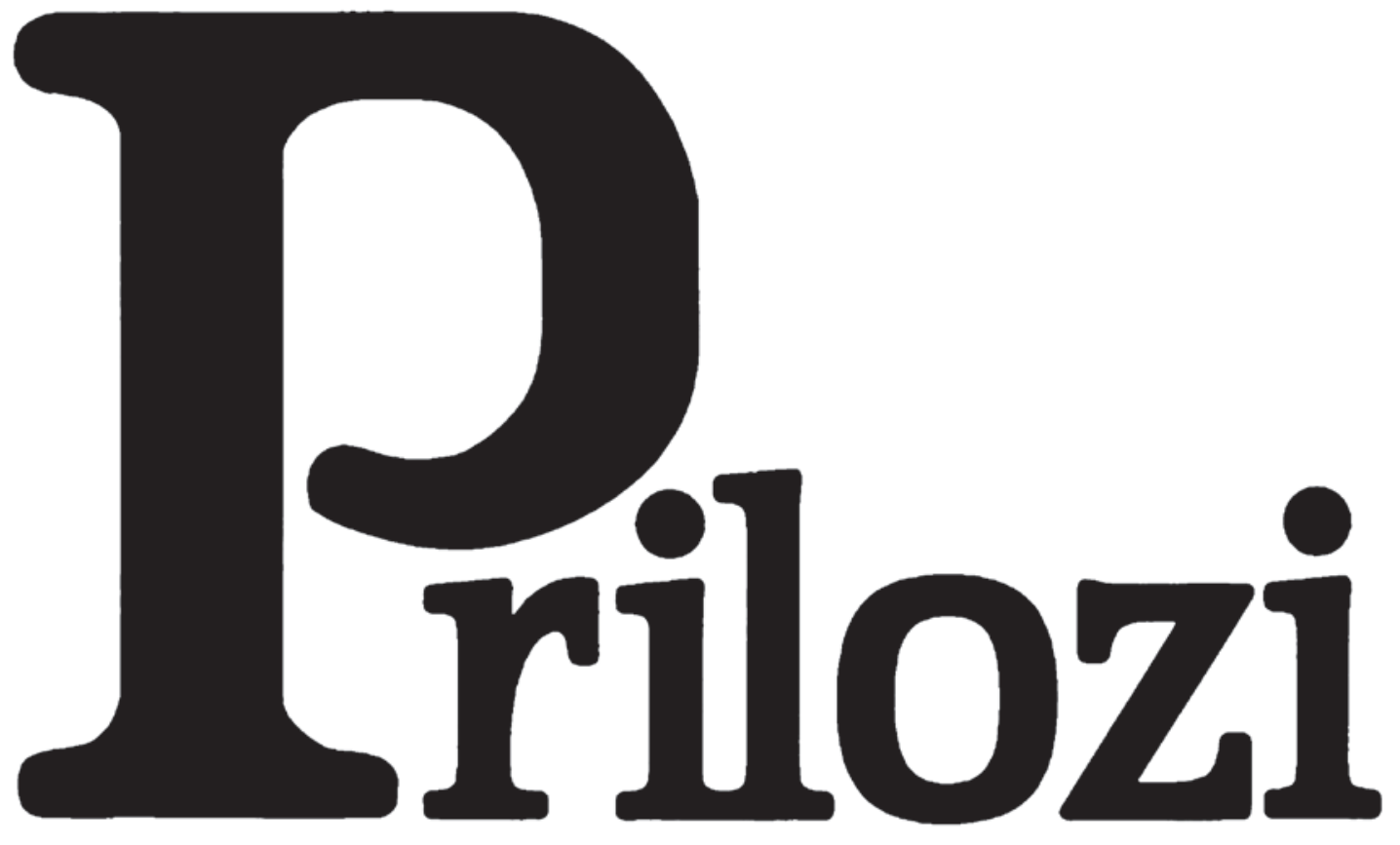

Instituta za arheologiju u Zagrebu 
Pril. Inst. arheol. Zagrebu, 37/2020

Str./Pages 1-234, Zagreb, 2020.

E-izdanja. Publikacija je dostupna u digitalnom obliku i otvorenom pristupu na

https://hrcak.srce.hr/prilozi-iaz

E-edition. The publication is available in digital and open access form at

https://hrcak.srce.hr/prilozi-iaz?lang=en

Ovaj rad licenciran je pod Creative Commons Attribution By 4.0 međunarodnom licencom / This work is licenced under a Creative Commons Attribution By 4.0 International Licence
Izdavač/Publisher

INSTITUT ZA ARHEOLOGIJU

INSTITUTE OF ARCHAEOLOGY

Adresa uredništva/Address of the editor's office Institut za arheologiju/Institute of archaeology

HR-10000 Zagreb, Ulica Ljudevita Gaja 32

Hrvatska/Croatia

Telefon/Phone ++385/(0)1 6150250

Fax $++385(0) 16055806$

e-mail: urednistvo.prilozi@iarh.hr

http://www.iarh.hr

Glavni i odgovorni urednik/Editor in chief

Marko DIZDAR

Tehnički urednici/ Technical editors

Marko DIZDAR

Katarina BOTIĆ

Uredništvo/Editorial board

Marko DIZDAR, Snježana VRDOLJAK, Viktória KISS (Budapest, HUN) (prapovijest/Prehistory), Goranka LIPOVAC VRKLJAN, Ivan RADMAN-LIVAJA (antika/ Antiquities), Tajana SEKELJ IVANČAN, Katarina Katja PREDOVNIK (Ljubljana, SLO), Natascha MEHLER (Wien, AUT), Juraj BELAJ, Tatjana TKALČEC (srednji vijek i novi vijek/Middle Ages and Modern era), Predrag NOVAKOVIĆ (Ljubljana, SLO) (metodologija/Methodology)

Izdavački savjet/Editorial advisory board

Dunja GLOGOVIĆ (Zagreb), Ivor KARAVANIĆ (Zagreb), Laszlo KÓVACS (Budapest, HUN), Kornelija MINICHREITER (Zagreb), Aleksandar RUTTKAY (Nitra, SK), Ivančica SCHRUNK (Minneapolis, USA), Željko TOMIČıĆ (Zagreb), Ante UGLEŠıĆ (Zadar)

Prijevod na engleski/English translation

Domagoj BUŽANIĆ, Kristina DESKAR, Dario HRUŠEVAR, Ana KONESTRA, Tamara LEVAK POTREBICA, Marko MARAS, Rory MACLEOD, Šime VRKIĆ, Mirna VUKOV

Lektura/Language editor

Ivana MAJER, Marko DIZDAR (hrvatski jezik/Croatian)

Marko MARAS (engleski jezik/English)

Korektura/Proofreads

Katarina BOTIĆ

Grafičko oblikovanje/Graphic design

Roko BOLANČA

Računalni slog/Layout

Hrvoje JAMBREK

Tisak/Printed by

Tiskara Zelina d.d., Sv. I. Zelina

Naklada/Issued

400 primjeraka/400 copies

Prilozi Instituta za arheologiju u Zagrebu uključeni su u sljedeće indekse/

Prilozi Instituta za arheologiju u Zagrebu are included in following indices:

DYABOLA - Sachkatalog der Bibliothek - Römisch-Germanische Kommission des Deutschen Archaeologischen Instituts, Frankfurt a. Main

Clarivate Analytics services - Web of Science Core Collection

CNRS/INIST - Centre National de la Recherche Scientifi que/L'Institut de I'Information Scientifi que et Technique, Vandoeuvre-lès-Nancy

EBSCO - Information servises, Ipswich

ERIH - European Reference Index for the Humanities, European Science Fundation, Strasbourg

SciVerse Scopus - Elsevier, Amsterdam 


\section{Sadržaj}

\section{Izvorni znanstveni radovi} MARIO NOVAK

Tragovi prapovijesnih pokapanja ljudi u špiljama dubrovačkoga područja

ŠIME VRKIĆ

NEDA KULENOVIĆ OCELIĆ

Prilog poznavanju prapovijesnih gradina na donjem toku rijeke Zrmanje

ANA KONESTRA

GORANKA LIPOVAC VRKLJAN

BARTUL ŠILJEG

The assortment of ceramic building materials from the pottery workshop of Sextus Me(u)tillius Maximus at Crikvenica (Croatia)

MIRJANA SANADER

MIRNA VUKOV

DOMAGOJ BUŽANIĆ

Promjena perspektive o ranim rimskim migracijama na Sredozemlju. Slučaj istočnoga Jadrana

\section{Contents}

\section{Original scientific papers}

\author{
DOMAGOJ PERKIĆ \\ MARIO NOVAK \\ Traces of prehistoric human burials in the caves of \\ the Dubrovnik area

\section{ŠIME VRKIĆ \\ NEDA KULENOVIĆ OCELIĆ} \\ A contribution to the study of the prehistoric hillforts \\ in the lower course of the River Zrmanja
}

\section{ANA KONESTRA GORANKA LIPOVAC VRKLJAN BARTUL ŠILJEG \\ Asortiman građevinske keramike iz keramičarske radionice Sexta Me(u)tillia Maxima $u$ Crikvenici (Hrvatska)}

\section{MIRJANA SANADER \\ MIRNA VUKOV \\ DOMAGOJ BUŽANIĆ}

A change of perspective on early Roman migrations in the Mediterranean. The case of the eastern Adriatic

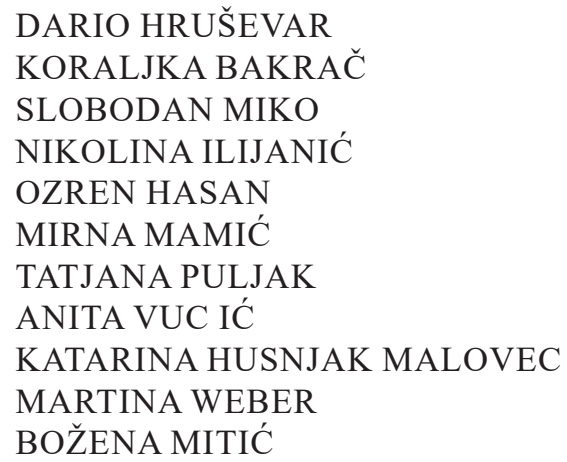

Dvije tisuće godina okolišnih promjena na području središnje Hrvatske - vegetacija, požari i hidrologija utjecani klimatskim prilikama i ljudskim pritiskom 
SINIŠA KRZNAR TAMÁS HAJDU

Kasnosrednjovjekovna i ranonovovjekovna populacija iz Ivankova, istočna Hrvatska: rezultati (bio)arheološke analize

\section{Prethodno priopćenje}

RENATA ŠOŠTARIĆ

HRVOJE POTREBICA

RENATA BONIĆ BABIĆ

MARIJA MARTINOVIĆ

TAMARA NOVAK

Grobnice halštatskih kneževa na lokalitetu Kaptol Čemernica: Arheobotanički nalazi iz tumula III i XI

211 IVANA OŽANIĆ ROGULJIĆ

JERE DRPIĆ

Clavi coctiles iz Cibala (Vinkovci)
SINIŠA KRZNAR

TAMÁS HAJDU

Late medieval/early modern population from Ivankovo, eastern Croatia: the results of the (bio)archaeological analysis

\section{Preliminary report}

RENATA ŠOŠTARIĆ

HRVOJE POTREBICA

RENATA BONIĆ BABIĆ

MARIJA MARTINOVIĆ

TAMARA NOVAK

Graves of Hallstatt Princes at Kaptol - Čemernica: Archaeobotanical Material from Tumuli III and XI

IVANA OŽANIĆ ROGULJIĆ JERE DRPIĆ

Clavi coctiles from Cibalae (Vinkovci) 


\title{
Promjena perspektive o ranim rimskim migracijama na Sredozemlju.
}

\section{Slučaj istočnoga Jadrana}

\section{A change of perspective on early Roman migrations in the Mediterranean.}

\section{The case of the eastern Adriatic}

\author{
Izvorni znanstveni rad \\ Antička arheologija \\ Original scientific paper \\ Roman archaeology \\ UDK/UDC 904:325(262.3-11)"-02/-00" \\ Primljeno/Received: 03. 02. 2020. \\ Prihvaćeno/Accepted: 25. 10. 2020.
}

\author{
MIRJANA SANADER \\ MIRNA VUKOV \\ DOMAGOJ BUŽANIĆ \\ Odsjek za arheologiju \\ Filozofski fakultet Sveučilišta u Zagrebu \\ Ivana Lučića 3 \\ HR-10000 Zagreb \\ msanader@ffzg.hr \\ mvukov@ffzg.hr \\ dbuzanic@ffzg.hr
}

\begin{abstract}
Migracije ljudi neizostavan su dio ljudske povijesti. One mogu biti i uzrok i posljedica, ali isto tako i katalizator društvenih promjena na nekome području. Migracije u doba rimskih osvajanja donedavno su u znanstvenoj raspravi bile slabo zastupljene u odnosu na izvještaje i komentare ratova i ostalih političkih zbivanja i aktera. Isto vrijedi i za sukobe na istočnoj jadranskoj obali. Zbog toga je cilj ovoga rada istražiti tragove i prirodu migracija koje su se događale uslijed ilirskih ratova i postupnoga nametanja Rima kao vladara ovog područja od 3. st. pr. Kr. pa do sredine 1. st. pr. Kr. ${ }^{1}$
\end{abstract}

Ključne riječi: istočna obala Jadrana, migracije, rimska osvajanja

Human migrations are an integral part of human history. They can be both a cause and a consequence, but also a catalyst for social change in an area. Until recently, migrations during the Roman conquests were poorly represented in the scientific discussion in relation to reports and comments on wars and other political events and figures. The same applies to conflicts on the eastern Adriatic coast. Therefore, the aim of this paper is to explore the traces and nature of migrations that occurred as a result of the Illyrian wars and the gradual imposition of Rome as the ruler of this area from the $3^{\text {rd }}$ cent. $B C$ until the middle of the $1^{\text {st }}$ cent. $B C .{ }^{1}$

Key words: eastern Adriatic coast, migrations, Roman conquest

Ljudski je rod od najranije povijesti migrirao s jednoga područja na drugo, bilo slijedom egzistencijalnih potreba uzrokovanih prirodnim nepogodama, bilo u potrazi za hranom ili zbog ratova. To se nije događalo bez poteškoća zbog toga što je naseljavanje na teritorij na kojem su već živjeli drugi zahtijevalo, baš kao i danas, određenu proceduru ako se događalo mirnim putem ili je izazivalo rat. Polazimo od toga da je i rimska okupacija zemalja Sredozemlja pokrenula seljenja stanovništva, u početku samo na italskome poluotoku, a kasnije, kako se Carstvo širilo, i iz jedne provincije u drugu. Cilj ovoga rada je istražiti tragove migracija

1 Ovaj rad financirala je Hrvatska zaklada za znanost projektom ,Razumijevanje rimskih granica: primjer istočnog Jadrana“" (IP-2018-01-4934).
Since ${ }^{1}$ its earliest known history, the human race migrated from one area to another. This happened either as a result of existential needs caused by natural disasters, or in search of food, or because of wars. It did not happen without difficulty. Settling in a territory where others already lived required, just as it does today, a certain procedure depending on whether it happened peacefully or provoked a war. We start from the fact that the Roman occupation of the Mediterranean lands initiated the migration of the population, initially only on the Italian peninsula, and later, as the Empire expanded, from one province to another. This

1 This work has been fully supported by the Croatian Science Foundation under the project "Understanding Roman Borders. The Case of the Eastern Adriatic“" (IP-2018-01-4934). 
bilo manjih ili većih grupa ljudi, pa i pojedinaca, na hrvatskome dijelu istočne obale Jadrana od početka rimske penetracije u 3. st. pr. Kr. pa do sredine 1. st. pr. Kr. Uz upotrebu specifičnih znanstvenih alata želimo raspoznati i raspraviti moguće modele koji bi trebali objasniti jesu li, kada i zbog čega pokrenute migracije. Ispitat ćemo nadalje, jesu li antičke migracije na istočnome Jadranu bile dvosmjeran proces $\mathrm{i}$ ako jesu tko je u njemu sudjelovao. Isto tako ćemo pokušati odgovoriti i na pitanje tko su bile prve pridošlice, na koji način su se ponašale u novome okruženju i kako su na njih reagirali starosjedioci.

\section{Kratki podsjetnik na antičke migracije u Sredozemlju}

Prije nego se posvetimo traženju odgovora o migracijama u antičko doba na istočnome Jadranu, podsjetimo se kratko na to kako su one započele na Sredozemnome moru. Prema dostupnim arheološkim nalazima prvi su bili Feničani koji su koncem 2. tis. pr. Kr., zaplovivši s obala Libanona, svoje matične postojbine, prema zapadu stigli i do Atlanti$\mathrm{ka}^{2}{ }^{2} \mathrm{Na}$ ta su putovanja kretali tragajući za resursima i novim životnim prostorima. U novim su krajevima započeli s utemeljivanjem trgovačkih uporišta i osnivanjem kolonija. Najslavnija fenička kolonija bila je Kartaga koju su oko 1200. g. pr. Kr. osnovali Sidonjani. ${ }^{3}$

Grci su u 11. st. pr. Kr. bilo iz trgovačkih interesa, političkih problema, neimaštine ili zbog neke druge nevolje krenuli (u skupinama oko 100 do 200 ljudi) u naseljavanje, odnosno u kolonizaciju novih područja (Milićević Bradač 2004: 11). U tim prvim migracijama Jonjani su naselili Egejske otoke i obalu Male Azije između Smirne i Mileta. Eolci iz Tesalije naselili su područja sjeverno od Smirne, a južno od Mileta naselili su se Dorani. Migracija Grka koju nazivamo Velika grčka kolonizacija, a u kojoj je sudjelovalo stanovništvo brojnih polisa, zbivala se između 750. i 580. g. pr. Kr. Tada su Grci naselili južnu Italiju, Siciliju, sjevernu Egeju kao i neke dijelove priobalja Crnoga mora.

lako su novoosnovana naselja pamtila tko su bili njihovi osnivači i odakle su krenuli u nove krajeve, bila su politički i gospodarski potpuno ili pak uglavnom neovisna od svojih matičnih naselja. Upravo je ta činjenica ono što ih, suprotno istome nazivu, čini različitim od novovjekovnih kolonizacija. Osim toga, doseljeni se Grci nisu previše uplitali u život domorodaca čije su resurse međutim uvelike iskorištavali.

Nešto posve različito bila je rimska dominacija Sredozemljem, jer je imala brojnih posljedica za stanovništvo od kojih je jedna bila i migracije stanovništva (Broadhead 2001: 69-89). Rimljani su tako različitim ritmom, a koji je ovisio o lokalnim prilikama, mijenjali gotovo sve aspekte javnoga, ali

2 Arheološki nalazi upućuju na zaključak da su u toj potrazi mogli stići ne samo do obala Afrike i Hispanije, nego i do Britanije (v. Markoe 2000: 103).

3 Međutim, Tirošani si bili ti koji su Kartagu 814. g. pr. Kr proširili utemeljenjem novoga naselja te je doveli do političkog, gospodarskog i kulturnog vrhunca (v. Docter et al. 2015). paper aims to investigate the traces of migrations of either smaller or larger groups of people and even individuals on the Croatian part of the eastern Adriatic coast since the beginning of Roman penetration in the $3^{\text {rd }}$ cent. $\mathrm{BC}$ until the middle of the $1^{\text {st }}$ cent. $B C$. Using special scientific tools, we want to identify and discuss possible models that should explain whether, when, and why migrations were initiated. We will further examine whether the ancient migrations in the eastern Adriatic were a two-way process and if so, who participated in it. We will also try to answer the questions of who the first newcomers were, how they behaved in the new environment, and how the natives reacted to them.

\section{A brief reminder on the ancient migration in the Mediterranean}

Before we turn our focus to the search for answers about ancient migrations in the eastern Adriatic, let us briefly recall how they began in the Mediterranean. According to available archaeological finds, by sailing from the coast of Lebanon, their homeland, at the end of the $2^{\text {nd }}$ millennium $\mathrm{BC}$, Phoenicians were the first who reached west to the Atlantic. ${ }^{2}$ They embarked on these journeys in search of resources and new living space. In the new lands, they began to establish trading strongholds and founded colonies. The most famous Phoenician colony was Carthage, which was founded by the Sidonians around $1200 \mathrm{BC} .^{3}$

In the $11^{\text {th }}$ cent. BC, the Greeks, either out of trade interests, political problems, poverty, or due to some other trouble, set out (in groups of about 100 to 200 people) to settle and colonize new areas (Milićević Bradač 2004: 11). In these first migrations, the lonians settled the Aegean islands and the coast of Asia Minor between Smyrna and Miletus. The Aeolians from Thessaly settled the areas north of Smyrna, and the Dorians settled south of Miletus. The migration of the Greeks, in which the population of numerous city-states took part, happened between 750 and $580 \mathrm{BC}$ and is called the Great Greek Colonization. During that time, the Greeks inhabited southern Italy, Sicily, the northern Aegean as well as some parts of the Black Sea coast.

Although the newly established settlements remembered who their founders were and where they came from, they were politically and economically completely or mostly independent of their home settlements. It is precisely this fact that, although they bear the same name, makes them different from modern colonization. Also, the immigrant Greeks did not interfere too much in the lives of the natives, whose resources, however, they made extensive use of.

Something completely different from this was the Roman domination of the Mediterranean because it had numerous consequences for the population, one of which was population migration (Broadhead 2001:69-89). Although at a varied pace, which depended on the local situation, the

2 Archaeological findings suggest that in this search they could have reached not only the coasts of Africa and Spain but also Britain (see Markoe 2000: 103)

3 However, the people of Tyros were the ones who expanded Carthage in 814 BC by establishing a new settlement and brought it to a political, economic and cultural peak (see Docter et al. 2105). 
i privatnoga života u osvojenim krajevima: gospodarstvo, religiju, kulturu i običaje. Slijedeći geografske i socijalne različitosti promijenili su i organizaciju prostora ne samo urbanizacijom, nego i razvojem ruralnih gospodarstava kao i beskrajnim prometnicama koje su sve te tečevine i povezivale. Uslijedile bi selidbe stanovništva iz jednoga kraja Carstva u drugi, što je bio slučaj i s istočnom obalom Jadrana.

No podsjetimo na to da su se za ilirsku obalu Rimljani zainteresirali nakon što su zavladali dobrim dijelom italskoga poluotoka i nakon što su 275. g. pr. Kr. pobijedili epirskoga kralja Pira (Plut. Pyrr. 26; Heftner 1997). Nakon toga su se upleli u Prvi punski rat (264. - 241. g. pr. Kr.) u koji su ušli strahujući od potpune kartažanske prevlasti nad Sicilijom. Smatrali su, naime, da bi Sicilija mogla poslužiti Kartažanima kao most prema Italiji. Nakon poraza Kartažani su Rimljanima, osim prepuštanja svojih posjeda na Siciliji, morali platiti i veliku reparaciju. $U$ podjeli golemoga plijena oduševljeno su sudjelovali ne samo rimska elita i rimski vojnici nego i saveznici. Prevlast u Italiji i Velikoj Grčkoj donio im je ne samo gospodarsku dobrobit, nego je i uvelike pojačao broj ljudstva koje su mogli angažirati u vojničkoj službi. Nakon ove pobjede se, kako se čini, među rimskim političarima počela javljati ideja o mogućem preuzimanju vlasti nad njima tada poznatim svijetom. Ta im se želja, nakon nešto više od tri stotine godina, i ostvarila kada je za vladavine Trajana Carstvo raspolagalo najvećim teritorijem (Wheeler 2010: 1185-1227; 2011: 191-219).

U pisanju povijesti Rimskoga Carstva kao i u komentarima povijesnih zbivanja, još od antičkih vremena, okušali su se mnogi historičari. Svi su oni ponudili svoje viđenje tijeka rimskih osvajanja, ali i svoje viđenje naravi rimskoga imperijalizma. ${ }^{4}$ Ti, vrlo slavni i danas citirani autori, nisu se, među-

4 Prije nego iznesemo nekoliko zanimljivih stavova slavnih historičara o rimskim osvajanjima podsjetimo da je leksem imperijalizam nastao u 16. st. iz latinskoga glagola impero 1. (upravljati, zapovijedati). Početkom 19. st. počelo se rabiti za Napoleonove pristaše i težnje njegovih nasljednika prema širenju vladavine sukladno želji za glavnom ulogom u političkome svijetu. Potom se pojam počeo rabiti na primjerima i usporedbama iz rimske povijesti, a u to doba je znao označavati i djelovanje modernih kolonijalnih država. U posljednje se vrijeme citira definicija imperijalizma koju je iznio Mattingly (2011: 6). Sažeta interpretacija njegove definicije bila bi da je imperijalizam dinamičan proces uspostave i održavanja carstva (v. i Werner 1972: 501-563; Kiely 2010: 2-8).

Evo nekoliko sažetih pogleda na temu rimske imperijalističke politike koji ilustriraju sav dijapazon različitosti i subjektivnosti u ocjenama vodećih historičara. Theodor Mommsen (1817. - 1903.), najslavniji njemački povjesničar (koji je uostalom za svoju povijest Rimskoga Carstva dobio i Nobelovu nagradu) bio je, kako se čini, svjestan da je ono što su Rimljani radili bilo surovo ratno osvajanje koje ne bi trebalo izazivati simpatije. Usprkos tome, u njegovim djelima može se zamijetiti poštovanje, moglo bi se reći i divljenje prema Rimljanima. Pa kako je iznad svega osjećao naklonost prema tome starom narodu, njegovoj kulturi i ostavštini, pronašao je i rješenje kako da ne sakrije ružnu istinu, a Rimljane ipak ostavi simpatičnima. On je, naime, okarakterizirao rimsku politiku kao defenzivni imperijalizam što je naravno contradictio in se (Mommsen 1856: 781-782; v. i Linderski 1984: 133-164; Jähne 2003: 89-108; Castignani 2012: 35-57). M. Holleaux je iznio teoriju po kojoj, ako je svedemo na nekoliko riječi, Rimljani nisu imali nikakav plan za sustavno osvajanje tuđih teritorija. Štoviše, on misli da Rimljani do Drugoga makedonskog rata nisu ni htjeli na Istok. Osim toga ističe da su sve rimske bitke do toga makedonskog rata bile defenzivne, dakle obrambene, a sve što se kasnije događalo da je bilo uzrokovano slučajnošću (Holleaux 1921: 312). Bengston je, pišući knjigu o grčkoj povijesti,
Romans changed almost all aspects of public and private life in the conquered areas: economy, religion, culture, and customs. By taking into account geographical and social differences, they changed the spatial organization. This change was brought about not only by urbanization but also by the development of rural economies as well as the endless roads that connected all these new undertakings. Following this, the population would move from one end of the Empire to the other, as was the case with the eastern Adriatic coast.

But let us recall that the Romans became interested in the Illyrian coast after conquering a good part of the Italian peninsula and defeating Pyrrhus, king of Epirus, in 275 BC (Plut. Pyrr. 26; Heftner 1997). After that, they got involved in the First Punic War (264 - 241 BC), which they entered fearing complete Carthaginian domination over Sicily. They thought that Sicily could serve the Carthaginians as a bridge to Italy. After their defeat, the Carthaginians had to pay large reparations to the Romans, in addition to leaving their possessions in Sicily. The huge spoils were enthusiastically divided not only between the Roman elite and Roman soldiers, but also their allies. Dominance in Italy and Magna Graecia brought them not only economic gain but also greatly increased the number of men they could engage in military service. After this victory, it seems, the idea of a possible takeover of power over the known world began to emerge among Roman politicians. After a little more than three hundred years this wish came true when, during the reign of Trajan, the Empire was at its largest extent (Wheeler 2010: 1185-1227; 2011: 191-219).

Since ancient times, many historians have tried to write down the history of the Roman Empire as well as to comment on historical events. They all offered their vision of the course of Roman conquests, but also their thoughts on the nature of Roman imperialism. ${ }^{4}$ These, today very famous

4 Before presenting some interesting views of famous historians on the Roman conquests, let us recall that the lexeme imperialism originated in the $16^{\text {th }}$ century from the Latin verb impero 1 . (to govern, to command). At the beginning of the $19^{\text {th }}$ century, it began to be used for Napoleon's supporters and the aspirations of his successors to expand his rule in accordance with the desire for a major role in the political world. Then the term began to be used on examples and comparisons from Roman history, and at that time it used to denote the activities of modern colonial states. Recently, the definition of imperialism given by Mattingly (2011: 6 ) is being widely cited. A concise interpretation of his definition would be that imperialism is a dynamic process of establishing and maintaining an empire (see also Werner 1972: 501-563; Kiely 2010: 2-8).

Here are a few concise views on the subject of Roman imperialist politics that illustrate the full range of diversity and subjectivity in the assessments of leading historians. Theodor Mommsen (1817 - 1903), the most famous German historian (who also won the Nobel Prize for his history of the Roman Empire) seemed to be aware that what the Romans were doing was a brutal conquest by means of war, which should not provoke sympathy. Nevertheless, one can notice respect, or perhaps admiration for the Romans in his work. So, above all, he felt affection for these ancient people, its culture and legacy, and he found a way how not to hide the ugly truth, and still leave the Romans worthy of sympathy. Namely, he characterized Roman politics as defensive imperialism, which is of course contradictio in se (Mommsen 1856: 781-782; see also Linderski 1984: 133-164; Jähne 2003: 89-108; Castignani 2012: 35-57). M. Holleaux put forward the theory that, if we reduce it to a few words, the Romans had no plan for the systematic conquest of foreign territories. Moreover, he believes that the Romans did not even want to go to the East until the Second Macedonian War. In addition, he points out that 
tim, osvrtali na migracije stanovništva koje su znali uzrokovati baš događaji koje su oni opisivali u svojim tekstovima. Migracije su došle u fokus tek kad su se u sklopu istraživanja suvremene ljudske mobilnosti poneki istraživači posvetili i migracijama u Rimskome Carstvu. ${ }^{5}$ Inače je terminus migracije prvi uporabio austrijski humanist Wolfgang Lazius u 16. st., u radu De aliquot gentium migrationibus, sedibus fixis, reliquiis, linguarumque initiis et immutationibus ac dialectis (Lazius 1557).

Migracije koje su slijedile nove političke prilike nastale slijedom rimskih osvajanja utjecale su ne samo etničku strukturu stanovništva, nego su dovele i do promjena u svim segmentima života. lako su u fokusu ovoga rada pridošlice na istočni Jadran, spomenimo da su nositelji promjena bili i oni i starosjedioci. Obje grupe su djelovale kao pružatelji i kao primatelji, što su zaključci s kojima su se istraživači antičkih migracija složili (de Ligt, Tacoma 2016: 1-22). Međutim, znanstvenici se ne mogu nikako usuglasiti u vezi dinamike mijena i načina kako su se mijene odvijale kao ni u vezi sa slojevima stanovništva koji su u sudjelovali u promjenama - da navedemo samo neka od više pitanja na koja se odavno pokušava naći odgovor. Oni su se u svojim istraživanjima koristili različitim konceptima kao i iskušavanjem teorija koje bi im se u tome trenutku učinile prihvatljivim i korisnim. Tako su se od početka 19. st. sva pitanja objašnjavala konceptom romanizacije, konceptom koji se koristi i danas, a koji se prvenstveno fokusira na kontakte Rimljana s autohtonim stanovništvom (Schörner 2005: V-XVI). Primjenom koncepta romanizacije koja je, da podsjetimo, kao pojam bio nepoznat u antičko vrijeme, bilježene su promjene u autohtonim društvima nastale slijedom međusobnih dodira, pa se istražuju procesi kao što su integracija, asimilacija i akulturacija, a kadikad i otpori osvojenih naroda (Nölke 2004). Istraživanja su uputila na zaključak da su narodi na osvojenim područjima, pa među njima i oni koji su obitavali na istočnome Jadranu, morali u procesu romanizacije, prije svega, poštovati novi ustroj vlasti i institucija po modelu rimske civilizacije. To se u početku osiguravalo nazočnošću vojnih trupa koje su omogućavale i jamčile nesmetano vladanje nove uprave (Sanader et al. 2019: 121-134). Usporedo

iznio zanimljivo mišljenje kojim kaže da su Rimljani i te kako znali kako zagrnuti svoj imperijalizam u plašt fraza o miru i sigurnosti, čime su varali svoje suvremenike (Bengston 2002: 453). Zanimljivo je i mišljenje F. W. Walbanka da su Rimljani bili dobri osvajači pa zaključuje: taj je pojam nabijen emocijama te onaj koji priča o rimskom imperijalizmu apriori daje rimskoj povijesti negativni predznak (Walbank 1963: 1-13). Neko vrijeme među povjesničarima nije bilo popularno rabiti riječ imperijalizam. No najdalje je otišao čuveni historičar F. Millard koji, među ostalim, upozorava na to da lekseme kao što su imperijalizam, dominantan, militarizam i kolonijalizam ne treba uopće rabiti jer su too crude (Millard 1984: 1-19). Izjava P. S. Derowa, premda dijelom i točna, da su Rimljani u svojoj želji za vladanjem uvijek uspjeli učinili da netko drugi započne rat, ne može umanjiti ni rimsku imperijalističku politiku kao ni njezine posljedice (Derow 1979: 1-15).

5 Jedan od najranijih radova bio je onaj A. J. N. Wilsona u kojem je, na osnovi literarnih i epigrafskih podataka, istražio migracije u 1. st. pr. Kr. iz Italije u provincije, pa tako i u Dalmaciju. On razlikuje migrante koji su se samovoljno naselili (private emigrants) od onih koje se naseljavaju pod paskom države (public guidance) (Wilson 1966: 68-75). and cited authors, did not, however, look back at the migrations of the population which were the result of the events they described in their texts. Migrations came into focus only when, as part of the study of modern human mobility, some researchers also devoted themselves to migration in the Roman Empire. ${ }^{5}$ The term migration was first used by the Austrian humanist Wolfgang Lazius in the $16^{\text {th }}$ century in his work De aliquot gentium migrationibus, sedibus fixis, reliquiis, linguarumque initiis et immutationibus ac dialectis (Lazius 1557).

The migrations that followed the new political circumstances created by Roman conquests affected not only the ethnic structure of the population but also led to changes in all segments of life. Although the focus of this paper is on the newcomers to the eastern Adriatic, let us mention that the bearers of change were both them and the natives. Both groups acted as providers and as recipients in this exchange, which has been agreed upon by researchers of ancient migrations (de Ligt, Tacoma 2016: 1-22). However, scientists cannot agree on the dynamics of change and the way it took place, nor on the classes within the population that were involved in these changes - to name just a few of the questions researchers have long sought to answer. In their research, they used different concepts and tested theories that seemed acceptable and useful to them at the time. Thus, from the beginning of the $19^{\text {th }}$ century, all issues were explained using the concept of romanization, a concept still used today, which primarily focuses on Roman contacts with the indigenous population (Schörner 2005: $\mathrm{V}-\mathrm{XVI}$ ). By applying the concept of romanization, which, let us recall, as a term was unknown in ancient times, changes in indigenous societies that were caused by mutual contact were recorded and so the processes such as integration, assimilation, acculturation, and sometimes the resistance of conquered peoples was explored (Nölke 2004). Research has led to the conclusion that the peoples of the conquered areas, including those who lived in the eastern Adriatic, had to, above all, in the process of romanization, respect the new structure of government and institutions based on

all the Roman battles until that Macedonian war were defensive and everything that happened later on was caused by chance (Holleaux 1921: 312). Writing a book on Greek history, Bengston expressed an interesting opinion that the Romans knew how to wrap their imperialism in a cloak of phrases about peace and security, thus deceiving their contemporaries (Bengston 2002: 453). The opinion of F. W. Walbank that the Romans were good conquerors is also interesting, so he concludes that this notion is charged with emotions and the one that tells the story of Roman imperialism a priori gives Roman history a negative connotation (Walbank 1963: 1-13). For some time it was not popular among historians to use the word imperialism. The famous historian F. Millard went the furthest, warning, among other things, that lexemes such as imperialism, dominant, militarism and colonialism should not be used at all because they are too crude (Millard 1984: 1-19). Although partly true, the statement by P. S. Derow, that the Romans in their desire to rule always succeeded in getting someone else to start a war, cannot diminish either Roman imperialist policy or its consequences (Derow 1979: 1-15).

5 One of the earliest works was that of A. J. N. Wilson in which, on the basis of literary and epigraphic data, he researched migrations in the $1^{\text {st }}$ cent. BC from Italy to the provinces and thus also to Dalmatia. It distinguishes migrants who have settled voluntarily (private emigrants) from those who settle under the auspices of the state (public guidance) (Wilson 1966: 68-75). 
s upravnim i gospodarskim promjenama uvedeni su rimski običaji, prije svega tečevine rimsko-italske civilizacije koju obilježava latinski jezik i kultura, i to ne samo u javnome, nego i privatnome životu. Mijenja se i duhovni život domaćega stanovništva pod utjecajem rimske religioznosti kao što se mijenja i autohtona religijska liturgija pod utjecajem rimskim kultnih radnji. ${ }^{6}$

Primjena koncepta romanizacije $u$ jednome je trenutku postala diskutabilna, a potom i izravno dovedena u pitanje (Hingley 1996: 35-48; 2005: 1-11; Woolf 1998: 1-24). Razlog je ležao u činjenici da znanstvenici nisu usuglasili zajednički stav o uzrocima, pokretačima i posljedicama kao ni o nositeljima procesa romanizacije. Zašto? Protivnici koncepta romanizacije objašnjavaju svoj otpor tvrdnjom da se njime previše naglašava rimski karakter u provincijama na štetu postignuća i kulture autohtonoga stanovništva. lako su pritom svjesni činjenice da su u zajedničkom Carstvu kulturne promjene u pojedinim zemljama znatnije nego li su bile prije njihova ulaska u Carstvo. Drugim riječima pojam romanizacija nije korektan jer upućuje na to da su sve kulture, osim rimske, bile promjenjive i to ne samo one kojima je Rim zavladao, nego i one rubne koje je samo dodirivao. Koncept romanizacije je previše pojednostavljeni pogled na događaje jer zanemaruje činjenicu kulturalne interakcije ma koliko god ona bila na rimskoj strani. Podsjetimo također da se u jednome trenutku u znanosti počeo razlikovati pojam romanizacije od pojma romaniziranja (Schörner 2005: V-XVI). Romaniziranjem se, naime, opisuje onaj dio romanizacije koji podrazumijeva nametanje rimskoga duha i kulture domaćem stanovništvu, a koji nije vezan isključivo uz vojna i politička djelovanja. Romaniziranje bi se možda moglo usporediti sa suvremenim postupcima stjecanja zarade uz pomoć sofisticiranoga nametanja vlastitih postignuća i pogleda u području odijevanja, glazbe, prehrane, tehnologije i drugog.

Iskoristit ćemo ovu prigodu da bismo podsjetili na zanimljiva razmišljanja koja su se počela javljati prije nekoliko desetljeća u sklopu istraživanja nazvanih material culture studies (Thrift 2018: 634-645). Ta se razmišljanja slažu tek s jednim dijelom onih procesa pod kojima podrazumijevamo koncept romanizacije. Tako se slažu s tezom da je Rim u provincijama nametnuo i upravni sustav i ekonomske zakone. No, ne slažu i da je nametnuo svoju kulturu. ${ }^{7}$ Zagovornici smatraju da se uz pomoć artefakata koji su se sačuvali iz razdoblja rimske vladavine ne može dokazivati kulturni stupanj lokalnoga stanovništva. Zbog čega? Zbog toga što su uvjerenja da se ni na jedan način ne može dokazati da je autohtono stanovništvo sudjelovalo u rimskoj kulturi. Drugim riječima, da je npr. posjećivalo one objekte koje su Rimljani

6 Budući da rimska vlast ne prisiljava niti zabranjuje domaće kultove, upravo je činjenica preuzimanja kultnih radnji, prije svega podizanje oltara s natpisima, ponudila najviše uvida $u$ autohtone kultove u provincijama diljem Carstva, pa tako i na istočnome Jadranu. Opsežan pregled bibliografije o antičkim kultovima u Hrvatskoj vidjeti kod: Vukov 2018.

7 U ovome slučaju se kulturom smatra skup kulturnih praktika, ne i objekata. the Roman model. This was initially ensured by the presence of military troops that enabled and guaranteed the undisturbed rule of the new administration (Sanader et al. 2019: 121-134). Along with the administrative and economic changes, Roman customs were introduced, primarily the heritage of Roman-Italic civilization marked by the Latin language and culture. This was happening not only in public but also in private life. The spiritual life of the local population was also changing under the influence of Roman religion, just as the autochthonous religious liturgy was changing under the influence of Roman cult practices. ${ }^{6}$

The application of the concept of romanization became debatable at one point and then directly questioned (Hingley 1996: 35-48; 2005: 1-11; Woolf 1998: 1-24). The reason lay in the fact that scholars did not agree on a common position on the causes, drivers, and consequences as well as on the bearers of the romanization process itself. Why? Opponents of the concept explain their resistance by claiming that it overemphasizes the Roman factor in the provinces to the detriment of the achievements and culture of the indigenous population. Although they are aware of the fact that in the common Empire, cultural changes in individual countries are more significant than they were before their entry into the Empire. In other words, the term romanization is not well suited because it implies that all cultures except the Roman culture were changeable, and not only those conquered by Rome but also the ones it bordered and only touched. The concept of romanization is too simplistic as a view of these events because it ignores the fact of cultural interaction, no matter how much it weighed on the Roman side. Let us also recall that at one point in science, the term romanization began to differ from the notion of romanizing (Schörner 2005: V-XVI). Romanizing describes that part of romanization which implies imposing the Roman spirit and culture on the local population, and which is not exclusively related to military and political activities. Romanizing could perhaps be compared to modern processes of profiting through the sophisticated imposition of one's own achievements and views in the fields of clothing, music, nutrition, technology, and more.

We will take this opportunity to recall interesting ideas that began to emerge decades ago as part of research called material culture studies (Thrift 2018: 634-645). These ideas correspond with only part of the processes found under the concept of romanizing. To be more specific, they agree with the hypothesis that Rome imposed in the provinces both an administrative system and economic laws. But they disagree with the idea that Rome imposed his culture. ${ }^{7}$ Proponents believe that the cultural degree of the local population cannot be proven using artifacts preserved from the period of Roman rule. Why would that be the case? They

6 Since the Roman government did not coerce or ban indigenous cults, the very fact of taking over cult activities, especially the erection of altars with inscriptions, offered the most insight into indigenous cults in the provinces throughout the Empire, including the eastern Adriatic. A comprehensive overview of the bibliography on the cults of Antiquity in Croatia, see in: Vukov 2018.

7 In this case, culture is considered to be a set of cultural practices, not objects. 
podizali kao što su odeoni ili teatri. Složit ćemo se s tim da danas ne možemo identificirati nekadašnje posjetitelje, ali isto tako ne može se dokazati ni da domaće stanovništvo nije posjećivalo kazališta. Još više sumnje u ovu teoriju izazivaju brojni rimski epigrafski grobni i votivni spomenici među kojima su nemali broj dali podići dedikanti autohtonoga porijekla (Vukov 2018). Zahvaljujući upravo tim epigrafskim spomenicima smatramo da je autohtono stanovništvo, ili barem jedan njegov dio, prihvatilo ne samo rimske kultne $\mathrm{i}$ pogrebne običaje nego i latinsko pismo. A kako su ti običaji sastavni dio rimske kulture, možemo s lakoćom pretpostaviti da je barem dio domaćega življa prihvatio i kulturu novih vladara.

Određena neodgovorena pitanja o načinu rimskih osvajanja i njihovih posljedica potaknula su, kako smo vidjeli, istraživače da potraže pomoć i izvan matične struke. Tako su različite postmodernističke teorije privukle veći broj sljedbenika, uglavnom anglosaksonskih istraživača koji su pomoću njih pokušali odgovoriti na otvorena pitanja. U ovoj prigodi izdvojit ćemo samo jednu koja se učinila koliko radikalnom u temeljnim postavkama toliko i neuspješnom u davanju sveobuhvatnih zadovoljavajućih odgovora. Radi se o novom polju istraživanja poznatom pod nazivom postkolonijalni studiji kojima se u posljednjoj četvrtini dvadesetoga stoljeća okrenulo više grana humanističkih znanosti, pogotovo lingvistika. Inspiraciju i poticaj su, među ostalim, našli primjerice i u Saidovoj knjizi o istočnjaštvu (Orientalism, London 1978) koji je pak, slijedeći poststrukturalističke trendove Derridaa i Foucaulta, kritizirao zapadnu inferiorizaciju orijentalnoga. Uslijedio je pravi pokret protiv kolonijalizma i imperijalizma. Takva je situacija bila vrlo plodna za etabliranje postmodernističkih ideja i među arheološkim teoretičarima. Rasprave o rimskome osvajanju Sredozemlja i njegovim posljedicama traju, kako znamo, s manje ili više intenziteta od devetnaestoga stoljeća do danas. No one su se dodatno rasplamsale devedesetih godina dvadesetoga stoljeća nakon objave Millettove knjige u kojoj je autor pokušao pronaći odgovor na još neodgovorena pitanja o romanizaciji Britanije i to upravo primjenom postkolonijalne teorije. Poklonici te teorije svoj su prostor pronašli u kritici najprije ekspanzionističkoga ratnog osvajanja, a kasnije i imperijalističkoga načina vladanja Rimljana (Millett 1999; Young 2003). U to je doba oblikovana i kolonijalna teorija diskursa koja se bavi kritičkim preispitivanjem i reinterpretacijom. Radovi teoretičara koji su se bavili analizom kolonijalnoga diskursa fokusirali su se na preispitivanje historiografije, epigrafije i arheologije, pri čemu se Rimljani smatraju kolonizirajućom zapadnom silom, dok se indigeno pučanstvo poima kao kolonizirani narod. ${ }^{8} \mathrm{U}$ širem društvenom kontekstu, s onu stranu arheologije, posve je shvatljiva tendencija u zapadnim zemljama da se suoče i do kraja

8 Spomenimo da postkolonijalna teorija nije antikolonijalna, jer ona ne gleda uvijek i isključivo negativno na Rimljane. Reklo bi se da i ne može biti samo negativna, jer su Rimljani uveli brojne i pozitivne značajke u gotovo svim segmentima života autohtonih društava. believe that there is no way to prove that the indigenous population participated in Roman culture. In other words, to prove that they, for example, visited buildings erected by the Romans such as odeons or theaters. We will agree that today we cannot identify former theater visitors, but also it cannot be proven that the local population did not visit them. Even more doubts about this particular theory are caused by numerous Roman epigraphic tomb and votive monuments, among which a large number were erected by dedicants of autochthonous origin (Vukov 2018). Thanks to these epigraphic monuments, we believe that the indigenous population, or at least a part of it, accepted not only Roman cult and funeral customs but also the Latin alphabet. And since these customs are an integral part of Roman culture, we can easily assume that at least part of the local population also accepted the culture of the new rulers.

Certain unanswered questions about the manner of the Roman conquests and their consequences prompted, as we have seen, researchers to also seek help outside their profession. Thus, various postmodernist theories attracted a large number of followers, mostly English speaking researchers, who used them to try to answer the still unresolved questions. On this occasion, we will single out only one that has seemed as radical in the underlying settings as it has been unsuccessful in giving comprehensive satisfactory answers. This is a new field of research known as postcolonial studies, to which several branches of the humanities turned in the last quarter of the twentieth century, especially linguistics. Inspiration and encouragement were found, among other things, in Said's book Orientalism (London 1978), which, following the poststructuralist trends of Derrida and Foucault, criticized the Western belittlement of the Oriental. A real movement against colonialism and imperialism followed. Such a situation has been very favorable for the establishment of postmodernist ideas even among archaeological theorists. Discussions about the Roman conquest of the Mediterranean and its consequences have been going on, as we know, with more or less intensity from the nineteenth century to the present day. But they flared up further in the 1990s after the publication of Millett's book, in which the author tried to find answers to unanswered questions about the Romanization of Britain by applying postcolonial theory. Proponents of this theory found their place in the critique of first the expansionist war conquests and later the imperialist way of Roman governing (Millett 1999; Young 2003). At that time, the colonial discourse theory was formed, which deals with critical re-examination and reinterpretation. The work of theorists analyzing colonial discourse has focused on re-examining historiography, epigraphy, and archeology, with the Romans being considered a colonizing Western power, while the indigenous population is perceived as colonized people. ${ }^{8}$ In the broader social context, beyond archeology, there is a perfectly understandable tendency in Western countries to confront and fully explore

8 Let us mention that the postcolonial theory is not anti-colonial, because it does not always and exclusively look negatively at the Romans. It can be stated that it cannot be only negative because the Romans introduced numerous and positive features in almost all segments of life of indigenous societies. 
istraže svoju kolonijalnu povijest, pa ako se hoće i u svjetlu suvremenih znatno pojačanih migracija iz Afrike i Azije prema Europi. ${ }^{9}$

\section{Istočni Jadran i rane rimske migracije}

Usprkos brojnim raspravama i manje ili više prihvatljivim prijedlozima za rješavanje nepoznanica o promjenama, pa tako i o migracijama koje su se u antici zbivale na istočnoj jadranskoj obali, istina je da historičari nisu ponudili nova bitna saznanja koja bi mogla utjecati na naše spoznaje. Koliko smo malo odmakli u istraživanjima migracija na istočnoj jadranskoj obali izazvanih rimskom vladavinom najbolje svjedoče dvije monografije sličnoga naslova i iste tematike koje je u razdoblju od dvije godine objavio ugledni hrvatski izdavač (Džino, Domić Kunić 2013; Zaninović 2015). Prva monografija, Rimski ratovi u Iliriku. Povijesni antinarativ, pokušava kritičkim preispitivanjem reinterpretirati izvore u čemu su, autori na žalost, samo djelomično uspjeli, prije svega zbog nedostatnoga korištenja analogija iz suvremenih staropovijesnih istraživanja. Druga knjiga, Ilirski ratovi autora M. Zaninovića, pokazuje da autoru koncept romanizacije potpuno odgovara i da nema nikakvog problema s njegovom primjenom, kao što nema ni problema sa simpatičnim glorificiranjem Ilira. Nasuprot tome, istraživanja, na primjer F. Milivojevića (2017), predstavljaju pravo osvježenje jer se autor ne libi suočiti s dotad gotovo neistraženim temama.

Jesu li Rimljani osvajanjem istočnoga Jadrana potaknuli dvosmjerne migracije? Kad se u lliriku slijedom rimske okupacije pojavljuju prvi doseljenici, a kada ga napušta prvo domaće stanovništvo? Tko su bili ljudi koji su u svojem trajnom naseljavanju u iliričkim krajevima vidjeli svoj prosperitet i budućnost? Koje je i zbog čega autohtono stanovništvo napuštalo Ilirik? Što o ovim pitanjima govore izvori, a što svjedoči arheologija?

Da su se na osvojenom teritoriju događale promjene svjedoče nam, dakle, pisani izvori, no istinitost njihovih narativa može, ako je u posjedu relevantnih materijalnih dokaza, potvrditi jedino arheologija. $U$ traganju za istinom arheologiji je od velike koristi i spoznaja da je bez oslonaca na historiografiju tumačenje arheoloških nalaza u problemima. Naime, bez historiografije arheologija ne može strukturirati narativ. Odličan primjer je izbijanje ustanka Batona koji se dogodio 6. godine. Bez tekstova antičkih historičara ne bi se znalo ništa o tome ustanku, zbog toga što je otpor indigenih ostao nematerijalan jer je njegov arheološki horizont, još, nažalost, praktički nevidljiv. Inače je slučajustanka Batona i dobar primjer protivljenja rimskoj dominaciji, ali i primjer uspješne, barem početne, međusobne suradnje različitoga ilirskog autohtonog stanovništva. ${ }^{10}$

9 Već su se i 1979. dali vidjeti transparenti indijskih studenata koji su prosvjedovali i Londonu s tekstom: Mi smo ovdje, jer ste vi bili tamo.

10 Djelovanje domaćega stanovništva u provincijama nije bilo ograničeno samo na protivljenje i otpor Rimljanima nego i na suradnju s njima. To se događalo i u Iliriku, o čemu su nas obavijestili natpisi nekoliko domaćih odličnika kojima su Rimljani priznavali status predvodnika njihova naroda: princeps civitatis Dindariorum; princeps Desitiatium i praepo- their colonial history, even in the light of contemporary, significantly intensified migrations from Africa and Asia to Europe. ${ }^{9}$

\section{Eastern Adriatic and the early Roman migrations}

Despite numerous debates and more or less acceptable proposals for resolving the unknowns about the changes, including migrations, that took place in antiquity on the eastern Adriatic coast, historians have, indeed, not offered new essential evidence that could significantly affect our knowledge of it. How little we have advanced in terms of research of the migrations on the eastern Adriatic coast caused by Roman rule is best illustrated by two monographs with similar titles and the same topic published in a period of two years by a prominent Croatian publisher (Džino, Domić Kunić 2013; Zaninović 2015). The first monograph, Roman Wars in Illyricum. The historical anti-narrative tries to reinterpret the sources by critical re-examination, in which, unfortunately, the authors have only partially succeeded, primarily due to the insufficient use of analogies from contemporary ancient historical research. The second book, Ilyrian Wars by M. Zaninović, shows that the author is completely comfortable with the concept of romanization and that he sees no problem with its application, just as with the rather elegant glorification of the Illyrians. In contrast, the research of, for example, F. Milivojević (2017) is a real refreshment, as the author does not hesitate to deal with hitherto almost unexplored topics.

Did the conquering of the eastern Adriatic by the Romans stimulate two-way migrations? Following the Roman occupation, when did the first settlers appear in Illyricum, and when did the first natives leave? Who were the people who saw their prosperity and future in their permanent settlement in the Illyrian regions? Which part of the indigenous population left Illyricum and why? What do historical sources say about these issues, and what does archeology tell us?

Written sources claim that changes took place in the conquered region, but the truth of their narratives can only be confirmed by archeology, and only if it's in possession of relevant material evidence. In the search for truth, it is also very useful for archeology to be aware that without relying on historiography, the interpretation of archaeological findings faces problems. Without historiography, archeology cannot structure a narrative. A good example of this is the Batos' uprising, which took place in $6 \mathrm{AD}$. Without the texts of ancient historians, nothing would have been known about this uprising. The resistance of the indigenous population remained archeologically intangible because its archaeological horizon is still, unfortunately, practically invisible. Apart from that, the case of the Batos' uprising is a good example of opposition to Roman domination, but also an example of successful cooperation of various indigenous Illyrian peoples, at least initially. ${ }^{10}$

9 Already in 1979, banners of Indian students were seen protesting in London with the text: We are here, because you were there.

10 The functioning of the native population in the provinces was not limited to opposition and resistance to the Romans but there was also co- 
lako se ovom prigodom posvećujemo migracijama izazvanima rimskom dominacijom, spomenimo da su na otocima istočnoga Jadrana najraniji antički migracijski procesi započeli doseljavanjem veće skupine Grka. Međutim, osim što posjedujemo podatke da su se doselili na srednjojadranske otoke, kao i podatke o njihovom kasnijem širenju na obalu, i dalje znamo premalo o konkretnim razlozima koji su ih potaknuli da napuste domovinu i nasele se na Jadranu. Isto tako, gotovo ništa ne znamo o njihovu utjecaju na autohtono stanovništvo koje je obitavalo na otocima, kao što ne znamo ni to je li je naseljavanje Grka izazvalo dvosmjernu migraciju, odnosno odlazak domaćih ljudi s otoka (Cambi et al. 2002; Sanader 2005: 413-421). Možda uspjeh recentnoga istraživanja nekropole sa senzacionalnim grobnim prilozima velike količine grčke keramike na korčulanskome lokalitetu Kopila unese više svjetla u dosadašnja saznanja (Radić et al. 2017: 148-203).

U 3. st. pr. Kr. doplovili su Rimljani, pod krinkom zaštite trgovačkih brodova od nasilništva i gusarenja autohtonoga stanovništva, u vode istočnoga Jadrana, na obale onoga područja koje su nazivali Ilirikom, a njegove stanovnike Ilirima. ${ }^{11}$ Slijedećih skoro tri stotine godina, s manjim ili većim prekidima, Rimljani su vodili protiv Ilira nesmiljene borbe obilježene brutalnim bitkama i kratkoročnim naizmjeničnim pobjedama obiju zaraćenih strana. Iz toga dugotrajnog sukoba Rimljani su izašli kao pobjednici slijedom čega su osvojili najprije jadransku obalu i otoke, a potom i unutrašnjost Ilirika do međuriječja Save, Dunava i Drave (Zaninović 1999: 209-222; Sanader 2008: 61-64). Prve sukobe kao i sva slijedeća ratovanja u Iliriku opisali su antički, a podrobno i nebrojeno puta komentirali moderni historičari među kojima su i oni hrvatski. ${ }^{12}$ Oni se, međutim, u svojim opisima i komentarima nisu posebno osvrtali na migracije koje su nakon rimskoga osvajanja uslijedile u lliriku. Spominjali su samo poslanike, vojske i njihove zapovjednike koji su jednako kao i trgovci u osvit rimskoga osvajanja priobalnih ilirskih krajeva bili, bez obzira zadržali se kraće ili duže, ipak samo u prolazu. ${ }^{13}$ Zanimljiva je vijest koju donosi Polibije (II. 12) da je nakon završetka Prvoga ilirskog rata dio vojske i pridruženih domaćih snaga ostao na osvojenom teritoriju u okolici Di-

situs et princeps Iapodum (ILJug 1544 = EDCS-10100534; ILJug 1582 = EDCS-10100565; CIL 03, 14324 = EDCS-32300071 i CIL 03, $14326=$ EDCS-31300292).

11 O razlozima koji su potaknuli Rimljane na osvajanje Ilirika napisano je dosta tekstova. Opširna bibliografija nalazi se u jednome od posljednjih komentara tih događaja u kojem autor iznosi tezu da su ilirski ratovi (posebice prvi) bili početak rimske aktivne politike prema istoku. $U$ toj je odluci igrao veliku ulogu i pritisak ekonomski orijentiranih interesnih grupa (Pohl 1993: 58-94). Slična zanimljiva razmišljanja mogu se pročitati i u disertaciji F. Milivojevića (2017: 321 i dalje).

12 Vidjeti bibliografiju o ilirskim ratovima kod: Čače 1979: 43-125; Džino, Domić Kunić 2013 i Zaninović 2015. Valja izdvojiti i radove S. Bilić Dujmušića s, po nama, novim i zanimljivim pogledima na te događaje i njihove posljedice (Bilić Dujmušić 2001; 2004).

13 Tako izvori spominju na primjer poslanike Gaja i Lucija Korunkanija i konzule u Prvome ilirskom ratu Gneja Fulvija Centumala i Aula Postumija te konzule Lucija Emilija Paula i Marka Livija Salinatora u Drugome ilirskom ratu (Zonara, 8, 19).
Although on this occasion we dedicate ourselves to migrations caused by Roman domination, let us mention that the earliest ancient migration processes began on the islands of the eastern Adriatic with the immigration of a larger group of Greeks. However, although possessing data that they migrated to the central Adriatic islands, as well as data on their later spread to the coast, we still know too little about the specific reasons that prompted them to leave their homeland and settle in the Adriatic. We also know almost nothing about their impact on the indigenous population already living on the islands, just as we do not know whether the settlement of the Greeks caused two-way migrations or departure of locals from the island (Cambi et al. 2002; Sanader 2005: 413-421). Perhaps the success of recent research on the necropolis with a large amount of sensational funerary Greek pottery at the site of Kopila, on the island of Korčula, sheds more light on what is already known (Radić et al. 2017: 148-203).

In the $3^{\text {rd }}$ cent. BC, the Romans, under the guise of protecting merchant ships from the violence and piracy of the indigenous population, sailed into the waters of the eastern Adriatic, to the shores of what they called Illyricum, and its inhabitants Illyrians. ${ }^{11}$ For the next nearly three hundred years, with some interruptions, the Romans waged relentless battles against the Illyrians marked by brutal conflicts and short-term alternating victories on both sides. The Romans emerged victorious from this long-lasting conflict, as a result of which they conquered first the Adriatic coast and its islands, and then the interior of Illyricum to the area between the Sava, Danube, and Drava rivers (Zaninović 1999: 209-222; Sanader 2008: 61-64). The first conflicts, as well as all subsequent wars in Illyricum, were described in ancient times and commented on in detail and countless times by modern historians, including Croatian ones. ${ }^{12}$ However, in their descriptions and comments, they did not pay special attention to the migrations that followed the Roman conquest of Illyricum. They mentioned only the envoys, armies and their commanders who, just like the merchants at the dawn of the Roman conquest of the coastal Illyrian regions, were, regardless of whether they stayed for shorter or longer periods, yet only in passing. ${ }^{13}$ An interesting

operation. This also happened in Illyricum, as we are informed by the inscriptions of several native dignitaries to whom the Romans bestowed the status of the leader of their people: princeps civitatis Dindariorum; princeps Desitiatium and praepositus et princeps Iapodum (ILJug 1544 = EDCS-10100534; ILJug 1582 = EDCS-10100565; CIL 03, $14324=$ EDCS-32300071 and CIL 03, $14326=$ EDCS-31300292).

11 Many texts have been written about the reasons that prompted the Romans to conquer Illyricum. An extensive bibliography is found in one of the last commentaries on these events in which the author argues that the Illyrian wars (especially the first) were the beginning of Roman active policy towards the East. The pressure of economically oriented interest groups also played a major role in this decision (Pohl 1993: 58-94). Similar interesting thoughts can be read in F. Milivojević's dissertation (2017: 321 et seq.).

12 See the bibliography on the Illyrian wars in: Čače 1979: 43-125; Džino, Domić Kunić 2013 and Zaninović 2015. We should also mention the works of S. Bilić Dujmušić with, in our opinion, new and interesting views on these events and their consequences (Bilić Dujmušić 2001; 2004).

13 Thus, sources mention, for example, the envoys Gaius and Lucius Coruncani and the consuls in the First Illyrian War, Gnaeus Fulvius Cen- 
rahija. ${ }^{14}$ No, o uvjetima boravka tih rimskih trupa ne znamo ništa, ne znamo koliko je ljudstva bilo u vojničkim odredima, kao što ne znamo ni jesu li boravili na jednome mjestu ili su bili raspoređeni na više njih - možda čak na nekome lokalitetu na hrvatskoj obali. ${ }^{15}$

Vrijedi se podsjetiti da je ova vojska, kao i svaka, trebala logističku podršku, pogotovo u slučaju dugotrajnijega boravka, npr. zimovanja. Pretpostavljamo da se opskrbljivala iz domaćih resursa uz pomoć vojne logistike, a možda i privatnih italskih poduzetnika, zbog čega bi se mogao pretpostaviti i dolazak određenoga broja rimskih trgovaca. Podsjetimo da su trgovci, otkad su naučili ploviti morima, sveprisutni na Mediteranu, pa tako i na istočnome Jadranu, o čemu svjedoče arheološki nalazi, prije svega keramike, novca i metalnih predmeta (Suić 1953: 71-101; Batović 1976: 11-93; Mihovilić et al. 2005: 389-408; Miše 2012: 231-240). No, pojava trgovaca ne znači i njihov stalan boravak, odnosno doseljavanje. Isto tako ne znači da je, u velikoj većini slučajeva, za obavljanje trgovine s autohtonim stanovništvom u to vrijeme bilo potrebno utemeljiti trgovište ili neku drugu vrsta naselja u kojem bi stalno živjeli njihovi kompatrioti koji bi im pomagali u trgovini. Slijedom toga, predmeti pronađeni $u$ arheološkim istraživanjima, a koji su proizvedeni izvan područja na kojem su nađeni, mogu svjedočiti samo o trgovanju, ali ne mogu nam baš ništa reći o migracijama. ${ }^{16}$

Što se tiče zakupaca, prije svega rudnika (ili njihovih zastupnika), koji su silom prilika morali duže vrijeme boraviti uz zakupljeno dobro, čini se nevjerojatnim da bi u toj najranijoj fazi osvajanja llirika Rimljani započeli s iskorištavanjem prirodnih resursa. Osim toga obalna jadranska područja, jedina koja su u to vrijeme bila pod rimskom vlasti, nemaju zaliha rude. ${ }^{17}$ Rudnici su smješteni u unutrašnjosti, pa je za njihovu eksploataciju bilo potrebno najprije osvojiti te krajeve, potom osigurati mirnodopske uvjete nakon čega su tek mogli razmišljati o njihovu iskorištavanju i gospodarskim aktivnostima. ${ }^{18}$

14 Ovo je prvi puta da na istočnoj jadranskoj obali rimska vojska ostaje duže vrijeme kao kontrola, odnosno svojevrstan način osiguranja osvojenoga. Ratovanje je bila najvažnija zadaća rimske vojske, ali ne i jedina (Le Bohec 1993: 15-17).

15 Polibije $(I I, 11)$ kaže da je Postumije iz Brindizija u Apoloniju prebacio 20000 pješaka i 2000 konjanika. Dio vojske se, nakon završetka sukoba, vratio, a dio je ostao. Međutim, Polibije $(I I, 12)$ ne kaže koliko njih, ali spominje da je rimskoj vojsci pridružena i vojska koja se na tome području već nalazila.

16 Tu postavku potvrđuju i nalazi brojnih komada najstarijega rimskog novca pronađenoga na istočnome Jadranu (Bertol 2014: 111-142). O nalazima pokretnih predmeta u vojničkim postrojbama i trgovini tim predmetima vidjeti i: Sanader 2020: 149-157.

17 Strabon je o ilirskoj obali napisao da je izuzetno dobro opskrbljena lukama, kako duž same obale, tako i na susjednim otocima, da je sunčana i pogodna za plodove jer maslina i vinova loza tamo lako uspijevaju svugdje, osim na mjestima koja su tu i tamo potpuno neplodna. No, iako je ilirsko primorje takvo, ljudi su u ranijim vremenima vrlo malo uzgajali te kulture, dijelom zbog neznanja, a uglavnom zbog divljine stanovnika

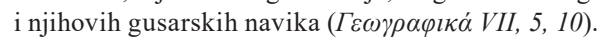

18 C̆uveni Marcijalovi stihovi (Epigr. X, LXXVIII, 1-8) u kojima Dalmaciju naziva zlatonosnom zemljom (aurifera terra) potječu s kraja 1. st. kada su već bili stvoreni svi uvjeti za iskorištavanje prirodnih resursa (Škegro 1999: 42-43). remark brought by Polybius (II. 12) is that after the end of the First Illyrian War, part of the army and associated local forces remained in the conquered territory in the vicinity of Dyrrachion..$^{14}$ However, we do not know anything about the circumstances surrounding these Roman troops, we do not know how many people were in these military detachments, just as we do not know whether they stayed in one place or were deployed in several of them - maybe even on a site on the Croatian coast. ${ }^{15}$

It is worth remembering that this army, like any other, needed logistical support, especially in the case of a longer stay, e.g., wintering. We assume that it was supplied from domestic sources with the help of military logistics, and perhaps also Italian entrepreneurs, which is why the arrival of a certain number of Roman merchants could be assumed. It should be reminded that since they learned to sail the seas, merchants are ubiquitous in the Mediterranean and thus also in the eastern Adriatic, as evidenced by archaeological finds primarily of ceramics, coins and metal objects (Suić 1953: 71-101; Batović 1976: 11-93; Mihovilić et al. 2005: 389-408; Miše 2012: 231-240). However, the appearance of merchants does not mean their permanent residence or immigration. Nor does it mean that, in the vast majority of cases, to trade with the indigenous population at that time, it was necessary to establish a trading post or some other type of settlement in which their compatriots would live permanently to help them in trade. Consequently, objects found in archaeological research, and which were produced outside the area where they were found, can only testify to trade, but they cannot tell us anything about migration. ${ }^{16}$

As for the tenants, primarily for mines (or their agents), who by force of circumstances had to stay for a long time with the leased property, it seems unlikely that at this earliest stage of the conquest of Illyricum the Romans would begin to exploit natural resources. Besides, the Adriatic coastal areas, the only ones under Roman rule at the time, have no ore reserves. ${ }^{17}$ The mines were located in the interior, so for their exploitation, it was necessary to first conquer these areas,

tumalus and Aulus Postumius, and the consuls Lucius Emilius Paulus and Marcus Livius Salinator in the Second Illyrian War (Zonara, 8, 19).

14 This is the first time that the Roman army has remained on the eastern Adriatic coast for an extended period of time as a factor of control or a kind of way to secure the conquered. Warfare was the most important task of the Roman army, but not the only one (Le Bohec 1993: 15-17).

15 Polybius (II, 11) says that Postumius transferred 20000 infantry and 2000 cavalry from Brundisium to Apollonia. Part of the army returned after the end of the conflict and part remained, but Polybius $(I I, 12)$ does not say how many of them, and mentions that the Roman army was joined by the army that was already in the area.

16 This assumption is confirmed by the finds of numerous pieces of the oldest Roman coins found in the eastern Adriatic (Bertol 2014: 111-142). On the small finds of military units and trade in these objects, see also: Sanader 2020: 149-157.

17 Strabo wrote that the Illyrian coast was extremely well supplied with ports, both along the coast and on the neighboring islands, that it is sunny and offers good yield, because olives and vines thrive easily everywhere, except in those places that are here and there. completely infertile. But although the Illyrian coast is like that, people in earlier times didn't cultivate these cultures very much, partly because they were ignorant of them, and chiefly because of the wild nature of the inhabitants and their

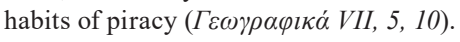


Kako je prikazano, migracije na istočnome Jadranu slijedom rimske penetracije nisu započele naseljavanjem došljaka nego autohtonoga stanovništva. O čemu se radi? Poraz Histra 177. g. pr. Kr. izazvao je veliki migrantski val, o čemu svjedoči Livije $(41,11,2-9)$. On je zapisao da su Rimljani, nakon uspješnoga ratovanja, prodali u roblje 5632 Histra (Čače 1979: 86-87). Kako se odlazak tako velikoga broja stanovništva odrazio na ukupnu društvenu i socijalnu sliku istarskoga poluotoka možemo samo spekulirati, ali ne može biti dvojbe o tome da je ta prisilna emigracija morala ostaviti višestruke tragove na tome području. Prodaja zarobljenika osvojenih teritorija bila je uobičajena nagrada za vojnike i ona se provodila nakon svih rimskih bitaka (i ne samo rimskih) na čitavome Mediteranu. Stoga vjerujemo da su se ilirski zarobljenici prodavali u roblje i nakon drugih izgubljenih bitaka, što znači da je do prisilnoga iseljavanja, slijedom porobljavanja, moglo doći odmah nakon završetka Prvoga ilirskog rata. Možda u nekim slučajevima zarobljenici nisu bili odmah prodani u roblje nego su bili prodani nakon što bi ih se u trijumfu, vezane lancima, provelo Rimom kao što je bio slučaj 23. veljače 167. g. pr. Kr. kada je, u Ancijevom trijumfu, gradu predstavljen posljednji ilirski vladar Gencije (Livije XLV, 43). No to dakako nije na stvari ništa mijenjalo ni u pogledu njihove zle sudbine, ni u pogledu činjenice da su ta područja poslije svakoga poraza ostajala bez dijela stanovništva, što je moralo sa sobom nositi negativne posljedice.

$\mathrm{U}$ još nekim slučajevima Rimljani su nasilno iseljavali stanovništvo iz llirika, ali ne muškarce, žene i djecu, nego samo za vojničku službu sposobne mladiće. Radi se o uobičajenom novačenju mladih muškaraca koje su Rimljani provodili u svim zaposjednutim krajevima, pri čemu bi ti novaci potom služili u rimskim pomoćnim trupama stacioniranim daleko od svoje domovine (Kraft 1951).

Istraživanja su pokazala da se, uz ova prisilna emigriranja, iz llirika odlazilo i svojevoljno, no to se događalo u razdobljima koje nisu obuhvaćena ovim radom. ${ }^{19}$ Ovdje nisu obuhvaćeni ni veterani koje su rimske vlasti naseljavali na novoosvojenim zemljama, pa tako i na prostoru llirika. Njima su se, naime, prilikom časnoga otpusta, između ostalih nagrada, dijelili i posjedi, što je značilo i njihov trajni boravak u novome kraju. ${ }^{20}$ Razdoblje koje nije obuhvaćeno ovim radom ono je u kojem se domaće stanovništvo bilo prilagodilo novome načinu života prihvaćanjem rimskih običaja. Autohtono stanovništvo ilirske obale nije zapisivalo, zapisivali su osvajači i to, naravno, na osnovi njihovih informacija o događajima, sudionicima i topografiji. Preuzimanjem rimskih običaja ta se nepovoljna situacija dijelom promijenila i

19 Tako je npr. poznato 350 spomenika koji svjedoče o ljudima iz provincije Dalmacije koji su, u različitim vremenima i iz različitih razloga, boravili izvan matične provincije (v. Demicheli 2012).

20 Iako S. Roselaar smatra da su veterani bili slobodni izabrati gdje će živjeti, nama se čini da to nije uvijek bilo tako (Roselaar 2016: 138-157). Razlog vidimo u činjenici što se dijeliti mogla samo novookupirana zemlja, budući da je ona starija bila već podijeljena i naseljena. Dakle, imali su izbor ili se naseliti gdje ima mjesta ili odustati od imanja (Sanader et al. 2007: 11-30). then provide peaceful conditions after which it was possible to consider their exploitation and economic activities. ${ }^{18}$

It is shown that migrations in the eastern Adriatic following Roman penetration did not begin with the settlement of the newcomers but of the indigenous population. What happened? The defeat of the Histrians in $177 \mathrm{BC}$ caused a large wave of migrants, as evidenced by Livy (41, 11, 2-9). He wrote that after a successful war, the Romans sold 5632 Histrians into slavery (Čače 1979: 86-87). Exactly how the departure of such a large number of people affected the overall social image of the Istrian peninsula, we can only speculate, but there can be no doubt that this forced emigration must have left multiple traces in the area. The selling of prisoners from conquered territories was a common reward for soldiers and it was carried out after all Roman battles (and not only Roman ones) in the entire Mediterranean. We, therefore, believe that Illyrian prisoners were sold into slavery after other battles they lost, which means that forced emigration, following enslavement, could have occurred immediately after the end of the First Illyrian War. Perhaps in some cases the captives were not immediately sold into slavery but were sold after being presented as a part of a triumph, bound in chains, in Rome, as was the case on $23^{\text {rd }}$ of February, $167 \mathrm{BC}$, when, in Anicius' triumph, the city presented the last Illyrian ruler, Gentius (Livy $X L V$, 43). But this, of course, did not change anything, neither in terms of their ill fate nor in terms of the fact that these areas were left without a part of their population after each defeat, which had to have negative consequences.

There are other cases of Romans forcibly emigrating the population from Illyricum, but not men, women, or children, but only young men capable of military service. It is the usual recruitment of young men carried out by the Romans in all occupied territories, with these recruits then serving in Roman auxiliary troops stationed far from their homeland (Kraft 1951).

Research has shown that in addition to these forced emigrations from Illyricum, people also left voluntarily, but this occurred in periods not covered by this paper. ${ }^{19}$ This also does not include veterans who were settled by the Roman authorities in the newly conquered lands, including Illyricum. During their honorable release, among other rewards, estates were distributed to veterans, which caused their permanent stay in the new area. ${ }^{20}$ The period not covered by this paper is that in which the native population had adapted to a new way of life by accepting Roman customs. The indigenous population of the Illyrian coast

18 Marcial's famous verses (Epigr. X, LXXVIII, 1-8) in which he calls Dalmatia a gold-bearing land (aurifera terra) date from the end of the $1^{\text {st }}$ cent. AD when all the conditions for the exploitation of natural resources had already been created (Škegro 1999: 42-43).

19 For example, 350 monuments are known that testify to people from the province of Dalmatia who, at different times and for different reasons, resided outside their home province (see Demicheli 2012).

20 Although S. Roselaar believes that veterans were free to choose where to live, it seems to us that this was not always the case (Roselaar 2016: 138-157). We believe the reason lies in the fact that only the newly occupied land could be divided, since the older one had already been divided and inhabited. Thus, they had the choice to either settle where there was a place for them or give up the property (Sanader et al. 2007: 11-30). 
to, prije svega, zahvaljujući podizanju epigrafskih spomenika, oltara i stela. Domoroci su nam tako ostavili dokaz svoje egzistencije, ali i prihvaćanja novoga načina života. Ipak, podsjetimo da je samo mali broj rimskoga stanovništva mogao financirati spomenik. R. Knapp (2012) piše da je 0,5 posto Rimljana bilo u posjedu 80 posto sredstava, pa među njima treba tražiti one koji su podizali spomenike. Većina rimskoga svijeta nije imala sredstva za takve aktivnosti, zbog čega o njima danas ne znamo ništa. Ipak, usuđujemo se pretpostaviti da oni koji bi uspjeli doći do novca ne bi mijenjali rimski način života i običaje, nego su brže bolje činili isto što i oni koji su prije njih raspolagali dovoljnim financijskim sredstvima. Spomenike na kojima se pojavljuju imena dedikanata analizirali su G. Alföldy (1969) za Dalmaciju i M. Križman (1991) za Istru. Na taj su način izradili, da parafraziramo $M$. Križmana, svojevrsne imenike stanovništva ilirske obale iz razdoblja rimske vladavine (Križman 1991). lako još nisu izrađene statistike etnika dedikanata, poznato je da su spomenike podizali i došljaci i autohtoni, rimski građani i oslobođenici, pa čak robovi.

Ovim radom je, kako je više puta naglašeno, obuhvaćeno najranije razdoblje rimskih osvajanja istočnoga Jadrana. O tome razdoblju većina današnjih saznanja crpljena je iz pisanih izvora, a tek poneki podatak iz arheoloških spomenika. Čini se, dakle, da su migracije u prvim vremenima rimske prisutnosti na istočnome Jadranu bile jednosmjerne jer u migracije ne ubrajamo dolazak i duži ili kraći boravak pripadnika prvih rimskih vojnih formacija, osvajača toga teritorija, već spomenute prisilne emigracije, prisilna iseljavanja prodajom dijela stanovništva u roblje ili regrutacijom mladića u rimsku vojsku. $U$ jednome trenutku su migracije postale dvosmjerne, i to onda kada su se za trajno naseljavanje stvorili sigurnosni uvjeti. Ti su se uvjeti počeli oblikovati nakon 59. g. pr. Kr. kada je Gaj Julije Cezar imenovan upraviteljem Cisalpinske Galije i Ilirika. ${ }^{21}$ Dobivanje provincijskoga statusa za sve osvojene zemlje, pa tako i za llirik, značio je uvođenje rimskoga načina upravljanja koji je donosio stabilnu vlast, odnosno mirnodopske uvjete (Sanader et al. 2019: 121-134). Tek tada je moglo biti osigurano manje-više pouzdano okruženje za iskorištavanje provincijskih gospodarskih resursa. Istovremeno se tek tada mogla stvoriti povoljna situacija za dolazak većega broja doseljenika iz Carstva kao i za svojevoljni odlazak autohtonoga stanovništva (Piso 2008). Takvu povoljnu situaciju mogla je osigurati samo vojska, legionari i pomoćne trupe, koja je prije svih pristizala u novoosvojene zemlje, pa tako i na istočni Jadran. Oni su štitili osvojeno i osiguravali miran dolazak različitih dužnosnika na nove položaje, prije svega upravitelja, njihov entourage kao i uredske svite. Tek tada su slijedili oni koji su svojevoljno sudjelovali u migracijama, svi oni koji su tragali za profitom ili oni koji su tražili bolje uvjete života od onih koje su imali usvojim zavičajima.

21 Konstituiranje ove provincije pratili su brojni, prije svega, ratnički problemi, kao npr. rat Cezara i Pompeja, Oktavijanova osvajanja u Iliriku (35. - 33. g. pr. Kr.) i konačno ustanak Batona (6. - 9. g. po. Kr.). did not record, the conquerors recorded, and, of course, this was done based on information available to them about the events, their participants, and topography. With the adoption of Roman customs, this unfavorable situation changed in part, primarily due to the erection of epigraphic monuments, altars, and stelae. The natives thus left us proof of their existence but also of accepting a new way of life. However, let us remind ourselves that only a small number of the Roman population could finance a monument. R. Knapp (2012) states that 0.5 percent of the Romans owned 80 percent of the wealth, so among them, one should look for those who erected monuments. Most of the Roman world did not have the means to fund such activities, which is why we know nothing about them today. Yet we dare to assume that those who managed to get the funds would not change Roman customs and way of life, but rather did the same as those who had sufficient financial means before them. Monuments on which the names of their dedicants appear were analyzed by G. Alföldy (1969) for Dalmatia and M. Križman (1991) for Istria. In this way, to paraphrase M. Križman, they created a kind of directories of the population of the Illyrian coast from the period of Roman rule (Križman 1991). Although statistics on the ethnicity of the dedicators have not yet been compiled, it is known that the monuments were erected by newcomers and natives, Roman citizens and freedmen, and even slaves.

This paper, as has been repeatedly emphasized, covers the earliest period of the Roman conquests of the eastern Adriatic. Most of today's knowledge about that period was drawn from written sources and only some data from archeological monuments. It seems, therefore, that migrations in the earliest period of the Roman presence in the eastern Adriatic were one-way because they do not include the arrival and longer or shorter stay of members of the first Roman military formations, conquerors of the land, but the already mentioned forced emigration, which occurred by selling part of the population into slavery or by recruiting young men into the Roman army. At one point, when peaceful conditions for permanent settlement were created, migrations became two-way. These conditions began to take shape after 59 BC when Gaius Julius Caesar was appointed governor of Cisalpine Gaul and Illyricum. ${ }^{21}$ For all conquered territories, including Illyricum, obtaining provincial status meant the introduction of the Roman way of governing, which brought stable power, i.e. peaceful conditions (Sanader et al. 2019: 121-134). Only then could a more or less reliable environment be provided for the exploitation of provincial economic resources. At the same time, a favorable situation was being created for the arrival of a larger number of immigrants from the Empire as well as for the voluntary departure of the indigenous population (Piso 2008). Such favorable conditions could be ensured only by the army, legionnaires and auxiliary troops, which arrived first in the newly conquered territories, including the eastern Adriatic. They protected what was conquered

21 The constitution of this province was accompanied by numerous, primarily war problems, such as the war of Caesar and Pompey, Octavian's conquests of Illyricum (35 - $33 \mathrm{BC})$, and finally the Batos' uprising (6-9 AD). 


\section{Udruženja rimskih građana na istočnome Jadranu}

Kako smo već spomenuli, izvori malo govore o migracijama na istočnome Jadranu tako da za vrijeme do polovice 1. st. pr. Kr. posjedujemo tek nekoliko indirektnih podataka koji mogu biti protumačeni na različite načine. Situacija se mijenja opisivanjem kasnijih događaja, pogotovo građanskoga rata kada historičari opisujući događaje u lliriku spominju i udruženja rimskih građana (conventus civium romanorum). Ta su udruženja u početku činile grupice došljaka po privatnoj osnovi, rimskih građana i oslobođenika u potrazi za profitom koji su, uglavnom u neposrednoj blizini postojećih naselja domaćih stanovnika, utemeljili svoje, trajne zajednice. Ti su doseljenici nastojali u svim segmentima oponašati rimski način života, pa tako i u upravljanju zajednicom. Slijedom toga su se udruživali u konvent, no o načinu na koji je ta samoprozvana organizacija djelovala unutar sebe ili kako su djelovali spram peregrinskih zajednica u čijoj su blizini bili naseljeni, ne znamo puno. Jedan od nekoliko podataka kojim, za sada, raspolažemo je onaj da je na čelu konventa stajao C(urator) C(ivium) R(omanorum) kojemu je znao pomagati kvestor. Unutar jedne provincije djelovao je i predstavnik više konvenata. Natpis jednoga takvog predstavnika, ako je danas izgubljeni spomenik dobro prepisan i protumačen, pronađen je i u provinciji Dalmaciji. ${ }^{22}$ Konventi već više od stoljeća izazivaju pozornost istraživača, pri čemu je E. Kornemann prvi sastavio svojevrsnu listu konvenata rimskih građana na osnovi do tada poznatih podataka. Ako je suditi po citiranosti, rimsku kolonizaciju je u posljednje vrijeme najuspješnije istraživao $F$. Vittinghoff (Kornemann 1891: 32, 76; Vittinghoff 1951; 1977: 3-51; Alföldy 1962a: 53-65; 1962b: 357-366.). ${ }^{23}$ Prvi su konventi rimskih građana osnivani duž jadranske obale, dakle na teritorijima koji su najranije pali pod rimsku vlast. ${ }^{24}$ Sigurnih arheoloških podataka koji govore o njima ima nekolicina, no usprkos tome još ne možemo ustanoviti kronologiju njihova osnivanja. Za sada smatramo da je većina osnovana najkasnije oko sredine 1. st. pr. Kr.

Tako, slijedom često citiranoga graditeljskog natpisa, pretpostavljamo rimsku zajednicu u Naroni, ako ne ranije,

22 CIL 03, 2733 = EDCS-28300058: Sex(tus) Iu[lius Sex(ti) f(ilius)] / Ani(ensi) Silva[nus Foro Iulii] / summus c[urat(or) c(ivium) R(omanorum) prov(inciae) Dalm(atiae)] / suffragio [eorum factus vet(eranus?)] / leg(ionis) VII C(laudiae) P(iae) F(idelis) aed/ilis col(oniae) Claudiae Aequi ab] / ordine primus [post col(oniam) ded(uctam) creatus] / IIIIvir i(ure) d(icundo) pont(ifex) [in col(onia?) Salona(?) 3] / in ag[ro] p(edes) [3] / h(oc) s(epulcrum) h(eredem) [n(on) s(equetur)].

23 Vittinghoffovi radovi naročito su značajni za datiranje utemeljenja pojedinih kolonija i municipija. On je, naime, doveo u sumnju dotadašnja datiranja po carskim gentilicijima i tribusima. U svojim istraživanjima kao dokaz iznesenim tvrdnjama često navodi baš primjere iz Dalmaciju, pri čemu kritizira Alföldija i Wilkesa zbog njihovih datiranja kolonija po tribusu. Osim toga, Vittinghoff je doveo u pitanje vrijeme osnivanja dalmatinskih kolonija uz pomoć navođenja imena cara ili nekoga uglednika kao oca ili zaštitnika kolonije. Smatra da njihova imena ne znače da je grad dobio status kolonije za života te osobe. Tom prilikom navodi grad Gades koji Agrippu naziva patronus parens, premda je sigurno da je Gades status kolonije dobio već za Cezara (Vittinghoff 1977: 12).

24 Počeci rimskog naseljavanja istočne obale Jadrana tek su od nedavno zainteresirali hrvatske historičare (Milivojević 2011: 189-210). and ensured the peaceful ascent of various officials to new positions, primarily governors, their entourage as well as administrators. Only then did those who voluntarily participated in migrations follow, all those who sought profit or those who sought better living conditions than those they had in their native homeland.

\section{Associations of Roman citizens on the eastern Adriatic}

As already mentioned, the sources say little about the migrations in the eastern Adriatic, so for the period up to the middle of the $1^{\text {st }}$ cent. $B C$ we have only a few indirect pieces of data that can be interpreted in different ways. The situation changes with the description of later events, especially the civil war, when historians, describing the events in Illyricum, also mention the associations of Roman citizens (conventus civium romanorum). These associations were initially made up of groups of newcomers, Roman citizens and freedmen in search of profit, who, mostly near the existing settlements of the natives, established their own, permanent communities. These settlers sought to imitate the Roman way in all segments of life, and thus also in the management of the community. Consequently, they joined into associations, but we do not know much about how these self-proclaimed organizations functioned within themselves, or how they acted concerning the peregrini communities near which they lived. One of the few pieces of data we have, for now, is that the conventus was headed by C(urator) C(ivium) R(omanorum), who was sometimes assisted by the quaestor. Within one province also operated a representative of several associations. The inscription of one such representative, if the now lost monument is well transcribed and interpreted today, was also found in the province of Dalmatia. ${ }^{22}$ These associations have been attracting the attention of researchers for more than a century, with $\mathrm{E}$. Kornemann being the first to compile a list of them based on previously known data. Judging by citations, Roman colonization has recently been most successfully researched by F. Vittinghoff (Kornemann 1891: 32, 76; Vittinghoff 1951; 1977: 3-51; Alföldy 1962a: 53-65; 1962b: 357-366). ${ }^{23}$ The first associations of Roman citizens were established along the Adriatic coast, i.e. in the territories that first fell under Ro-

22 CIL 03, 2733 = EDCS-28300058: Sex(tus) Iu[lius Sex(ti) f(ilius)] Ani(ensi) Silva[nus Foro Iulii] / summus c[urat(or) c(ivium) R(omanorum) prov(inciae) Dalm(atiae)] / suffragio [eorum factus vet(eranus?)] / leg(ionis) VII C(laudiae) P(iae) F(idelis) aed[ilis col(oniae) Claudiae Aequi ab] / ordine primus [post col(oniam) ded(uctam) creatus] / IIIIvir i(ure) d(icundo) pont(ifex) [in col(onia?) Salona(?) 3] / in ag[ro] p(edes) [3] / h(oc) s(epulcrum) h(eredem) [n(on) s(equetur)].

23 Vittinghoff's work is especially important for dating the founding of individual colonies and municipalities. Namely, he questioned the previous dating from imperial gentiles and tribes. In his research, he often cites examples from Dalmatia as evidence of his claims, criticizing Alföldy and Wilkes for their dating of the colonies by tribus. In addition, Vittinghoff questioned the time of the founding of the Dalmatian colonies by the name of the emperor or a dignitary as the father or protector of the colony. He believes that their names do not mean that the city received the status of a colony during that person's life. On that occasion, he cites the city of Gades, which calls Agrippa patronus parens, although it is certain that Gades received the status of a colony already in time of Caesar (Vittinghoff 1977: 12). 
onda najkasnije polovicom 1. st. pr. Kr. ${ }^{25}$ Osim toga, u okolici Narone pronađen je i jedan od najstarijih epigrafskih spomenika iz llirika. Radi se o natpisu uklesanome, kako se čini, na bazi kipa koji su dali podići braća Gaj Papije Celso i Marko Papije Kano. Kip je postavljen u čast Oktavijanovih uspjeha na Siciliji, zbog čega se natpis mogao precizno datirati u 33. g. pr. Kr. ${ }^{26}$ Premda još nismo sigurni zašto su kip postavili baš u današnjim Tasovčićima (BiH), mjesta koje je oko $12 \mathrm{~km}$ udaljeno od Narone Neretvom uzvodno, kao što ne znamo ni zašto su ova braća imala potrebu na taj način čestitati Oktavijanu na uspjehu koji je postigao u dalekoj Siciliji, sigurni smo da su njih dvojica bili doseljenici koji su se vlastitom voljom i potrebom nastanili u Naroni ili na imanju u njezinoj blizini. Jedan od najstarijih konvenata rimskih građana mogao je biti i onaj na otoku Visu, u grčkoj Isi. O tome neizravno svjedoči, danas nestali, natpis koji spominje Kvinta Numerija Rufa, Cezarova legata. ${ }^{27}$ Rufo je za vrijeme svoje službe o svome trošku dao obnoviti trijem jedne javne, nama danas nepoznate građevine u Isi. Wilson misli da je Rimljana u Isi bilo i ranije, što potkrepljuje tvrdnjom da je u poslanstvu Cezaru 56. g. pr. Kr. bio jedan Rimljanin iz Ise (Wilson 1966: 70). lako postoje mišljenja da je već 2 . st. pr. Kr. u Saloni postojao emporij, smatramo da je do ozbiljnijega naseljavanja moglo doći tek polovicom 1. st. pr. Kr. (Čače, Milivojević 2017: 425-450). Stoga mislimo da je konvent u Saloni mogao biti jednako star, ako ne i nešto stariji, nego li isejski (Brunšmid 1898: 33, br. 31). Ako je vjerovati izvorima, mogao je i u Epidauru u 1. st. pr. Kr. djelovati konvent rimskih građana (Bel. Alex, 44). ${ }^{28} \mathrm{Na}$ osnovi istoga izvora pretpostavlja se postojanje konventa u Jaderu već 48. g. pr. Kr. (Bell. Alex. 42,3). ${ }^{29}$ O konventu u Jaderu indirektno govori i jedan epigrafski spomenik na kojem je zabilježeno štovanje Cezarova kulta. ${ }^{30} \mathrm{Ako}$, temeljem procjene nekih istraživača, prihvatimo tezu da su Pola, Parentij i Jader dobile status kolonije nekako u isto vrijeme kad i Salona, Narona i Epidaur, pri čemu se najčešće spominje doba vladavine cara Augusta, onda možemo pretpostaviti da je i u njima već živio određe-

25 CIL 03, $1820=$ CIL 03, 8423 $=$ CIL 01, $02291=$ EDCS-24900091: Q(uintus) Safinius Q(uinti) f(ilius) / Sex(tus) Marius L(uci) l(ibertus) / mag(istri) Naro(nae) / Q(uintus) Marcius Q(uinti) f(ilius) / P(ublius) Annaeus Q(uinti) l(ibertus) Epic(adus) / q(uaestores) / tur(rim) fac(iendam) coir(averunt) (Mayer 2004: 233).

26 CIL 03, 14625 = ILS 8893 = HD044645 = EDCS-25002168: Imp(eratori) Caesari Divi f(ilio) / Sicilia recepta C(aius) Papius Celsu[s] / M(arcus) Papius Kanus fratres (Patsch 1912: 92-93, sl. 26).

27 CIL 03, 3078 = CIL 01, 759 = EDCS-24900094: Q(uintus) Numerius Q(uinti) Vel(ina) / Rufus leg(atus) patron(us) / portic(um) reficiund(am) / de sua pecun(ia) coer(avit) / idemque prob(avit) (Gabričević 1970: 553-562).

28 Hunc oppugnantem Epidaurum terra marique, ubi nostrum erat praesidium, adventu suo discedere ab oppugnatione coegit praesidiumque nostrum recepit (De bello Alexandrino, 44; v. i Glavičić 2008: 43-62).

29 Paucis navibus Iadertinorum, quorum semper in rem publicam singulare constiterat officium... (De bello Alexandrino, 42).

30 ILJug 211 = EDCS-10000302: L(ucio) Tettio / Epidiano ann(orum) $/$ VII L(ucius) Te[t]tius Sper/ches pater VIvir / Iul(ialis) viv $<u=O>_{s}$ posu/it l(ocus) d(atus) d(ecreto) d(ecurionum) (Giunio 2013: 199-219). man rule. ${ }^{24}$ There are few reliable archaeological data that speak of them, but we cannot yet establish the chronology of their founding. For now, we believe that the majority was founded around the middle of the $1^{\text {st }}$ cent. $B C$ at the latest.

Thus, following the often cited architectural inscription, we assume the Roman community at Narona, if not earlier, then no later than the middle of the $1^{\text {st }}$ cent. $B C .{ }^{25}$ In addition to this, one of the oldest epigraphic monuments from Illyricum was found in the vicinity of Narona. It is an inscription carved, it seems, on the base of a statue erected by the brothers Caius Papius Celsus and Marcus Papius Kanus. The statue was erected in honor of Octavian's successes in Sicily, which is why the inscription could be accurately dated to $33 \mathrm{BC} .{ }^{26}$ Although we are not yet sure why the statue was placed in today's Tasovčići (BiH), a place about $12 \mathrm{~km}$ upstream by the river Neretva from Narona, just as we do not know why these brothers needed to congratulate Octavian on his success in distant Sicily, we are sure that the two of them were immigrants who settled of their own free will and need in Narona or on a property near it. One of the oldest associations of Roman citizens could have been the one on the island of Vis, in the Greek city of Issa. This is indirectly evidenced by an inscription, now missing, which mentions Quintus Numerius Rufus, Caesar's legate. ${ }^{27}$ During his service, Rufus had the porch of a public building in Issa, unknown to us today, renovated at his own expense. Wilson believes that there were Romans in Issa before that, which he supports with the claim that a Roman from Issa was part of a mission to Caesar in 56 BC (Wilson 1966: 70). Although there are opinions that as early as the $2^{\text {nd }}$ cent. $B C$ there was an emporium in Salona, we believe that a more serious settlement could have occurred only in the middle of the $1^{\text {st }}$ cent. BC (Čače, Milivojević 2017: 425-450). We, therefore, think that the conventus at Salona could have been as old, if not somewhat older, than the one in Issa (Brunšmid 1898: 33 , no. 31). If the sources are to be believed, a conventus could have also existed in Epidaurus in the $1^{\text {st }}$ cent. BC (Bel. Alex, 44). ${ }^{28}$ Based on the same source, the existence of a conventus in lader is presumed as early as $48 \mathrm{BC}$ (Bell. Alex. $42,3){ }^{29}$ The coventus in lader is also indirectly mentioned

24 The beginning of Roman settlement on the eastern Adriatic coast have only recently begun to interest Croatian historians (Milivojević 2011: 189-210).

25 CIL 03, $1820=$ CIL 03, $8423=$ CIL 01, $02291=$ EDCS-24900091: Q(uintus) Safinius Q(uinti) f(ilius) / Sex(tus) Marius L(uci) l(ibertus) / mag(istri) Naro(nae) / Q(uintus) Marcius Q(uinti) f(ilius) / P(ublius) Annaeus Q(uinti) l(ibertus) Epic(adus) / q(uaestores) / tur(rim) fac(iendam) coir(averunt) (Mayer 2004: 233).

26 CIL 03, $14625=$ ILS $8893=$ HD044645 = EDCS-25002168: Imp(eratori) Caesari Divi f(ilio) / Sicilia recepta C(aius) Papius Celsu[s] / M(arcus) Papius Kanus fratres (Patsch 1912: 92-93, Fig. 26).

27 CIL 03, 3078 = CIL 01, 759 = EDCS-24900094: Q(uintus) Numerius Q(uinti) Vel(ina) / Rufus leg(atus) patron(us) / portic(um) reficiund(am) /de sua pecun(ia) coer(avit) / idemque prob(avit) (Gabričević 1970: 553-562).

28 De bello Alexandrino, 44: Hunc oppugnantem Epidaurum terra marique, ubi nostrum erat praesidium, adventu suo discedere ab oppugnatione coegit praesidiumque nostrum recepit (De bello Alexandrino, 44; see also Glavičić 2008: 43-62).

29 Paucis navibus Iadertinorum, quorum semper in rem publicam singulare constiterat officium... (De bello Alexandrino, 42). 
ni broj rimskih građana udruženih u konvent (Suić 1981: 142; Starac 2000: 27). Jesu li prvi doseljenici naselili samo spomenute gradove ili su se naseljavali i na drugim istočnojadranskim mjestima možemo, za sada, samo naslućivati. Ilirik je bio novo tržište koje su stali obilaziti trgovci, putujući majstori, obrtnici, njihovi pomoćnici. S doseljenicima su u llirik stizali i robovi. ${ }^{31}$ Spomenuti procesi koji su mijenjali etničku sliku Sredozemlja nisu zabilježeni samo na istočnoj jadranskoj obali, nego i u drugim rimskim provincijama (Eck 1999).

Rekli smo da su se antičke (i druge) migracije stanovništva počele proučavati tek posljednjih desetljeća. One na istočnoj obali Jadrana još uvijek čekaju svoj red, premda dokumenti, kako tekstovi antičkih pisaca tako i epigrafski zapisi i arheološka svjedočanstva o prastanovništvu i pridošlicama, nisu neznatni. ${ }^{32}$

\section{Umjesto zaključka}

Rim je bio politička velesila koja je koristila svoje vojne i političke potencijale u zauzimanju tuđega teritorija, odnosno u nametanju potpune kontrole nad stranim narodima $\mathrm{i}$ područjima, zbog čega je mogao razviti golemi utjecaj na Mediteranu, i ne samo na njemu, i to na duži period od bilo kojega carstva ili kulture tadašnjega i kasnijega svijeta. A ta je rimska politika, po našem mišljenju, imala samo dva cilja. Prvi je bio gospodarski probitak uz stjecanje što više materijalnih bogatstava, a drugi zaštita svoga statusa i tih stečenih dobara. Rimska je vlast promijenila mediteranski svijet. Između ostaloga i valovima migracija koje su, ne samo utjecale na promjenu etničke slike osvojenih zemalja, na povijest Sredozemlja općenito, nego su prouzročili i dramatične promjene okoliša u tim zemljama. ${ }^{33}$

lako su antičke migracije na prvi pogled slične jer su, prije svega, bile egzistencijalne naravi, one to nisu jer su među njima izrazite, prije svega, političke razlike. Tako su se npr. i fenički i grčki kolonizatori Sredozemlja, iskorištavajući kroz novoutemeljene gradove i trgovišta sve pogodnosti i resurse novoga teritorija, malo uplitali u život domaćega stanovništva, pa je ono ostajalo uglavnom izvan transformirajućih utjecaja kulturom i društvenim životom doseljenih susjeda. Način na koji su Rimljani dominirali prostorom bio je sasvim drugačiji, on je podrazumijevao potpunu, svekoliku prevlast nad narodima čije su teritorije zauzimali, čime su izazivali tektonske gospodarske i kulturne promjene. Svi ti procesi

31 O migracijama robova vidjeti: Silver 2016: 184-202.

32 Ta bi dokumentacija trebala biti i znatno bogatija, budući da su na hrvatskome priobalju provođena brojna arheološka iskopavanja. No ona su vrlo problematična jer većina materijala još nije analizirana niti objavljena. Dobar primjer i dokaz ovoj tvrdnji su i izdanja Hrvatskog arheološkog godišnjaka koja svjedoče o izvršenim arheološkim iskopavanjima nakon kojih su samo rijetki istraživači objavili iskopani pokretni materijal (v. Mesić 2005; 2006; 2007; 2009; Matica 2008; Wiewegh 2010; $2011 ; 2012 ; 2013 ; 2014 ; 2015)$.

33 Kako su te promjene mogle utjecati na okoliš istočne jadranske obale vidjeti: Sanader 2018: 9-15. on an epigraphic monument recording the worship of Caesar's cult. ${ }^{30}$ If we accept the thesis, which is based on the assessment of some of the researchers, that Pola, Parentium, and lader received the status of a colony at about the same time as Salona, Narona, and Epidaurum, most often dated in the reign of Emperor Augustus, then we can assume that already a number of Roman citizens lived there united in a conventus (Suić 1981: 142; Starac 2000: 27). For now, we can only guess whether the first immigrants settled only in the mentioned cities or also in other eastern Adriatic communities. Illyricum was a new market visited by merchants, traveling artisans, craftsmen, and their assistants. Slaves also arrived in Illyricum with the settlers..$^{31}$ The mentioned processes that were changing the ethnic structure of the Mediterranean were recorded not only on the eastern Adriatic coast but also in other Roman provinces (Eck 1999).

We have said that ancient (and other) migrations began to be studied only in recent decades. Those on the eastern Adriatic are still waiting their turn, although documents, both texts by ancient writers and epigraphic and archaeological records of indigenous peoples and newcomers, are not insignificant. ${ }^{32}$

\section{In place of a conclusion}

Rome was a political superpower that used its military and political potential to occupy foreign territory, that is, to impose complete control over foreign peoples and territories, which enabled it to develop a huge influence in the Mediterranean and beyond for a longer period than any empire or culture before and after. In our opinion, this Roman policy had only two goals. The first was economic gain with the acquisition of as much material wealth as possible, and the second was the protection of their status and those acquired goods. Roman rule changed the Mediterranean world. Among other things, this occurred through the waves of migration that not only influenced the change in the ethnic structure of the conquered countries, the history of the Mediterranean in general but also caused dramatic changes in the environment in those territories. ${ }^{33}$

Although ancient migrations are similar at first glance because they were primarily existential in nature, they are not. There are marked, primarily political differences between them. Thus, for example, the Phoenician and Greek colonizers of the Mediterranean, taking advantage of all the benefits and resources of the new territory through newly

30 ILJug 211 = EDCS-10000302: L(ucio) Tettio / Epidiano ann(orum) $/$ VII L(ucius) Te[t]tius Sper/ches pater VIvir / Iul(ialis) viv $<u=O>_{s}$ posu/it l(ocus) d(atus) d(ecreto) d(ecurionum) (Giunio 2013: 199-219).

31 On the migrations of slaves, see: Silver 2016: 184-202.

32 This documentation should be much richer, because numerous archeological excavations have been carried out on the Croatian coast. But they are very problematic because most of the material has not yet been analyzed or published. A good example and proof of this claim are the publications of the Croatian Archaeological Yearbook, which testify to the archeological excavations after which only a few researchers published the excavated small material (see Mesić 2005; 2006; 2007; 2009; Matica 2008; Wiewegh 2010; 2011; 2012; 2013; 2014; 2015).

33 For how these changes could have affected the environment of the eastern Adriatic coast see: Sanader 2018: 9-15. 
bili su snažno obilježeni i migracijama ljudi. S jedne strane, nakon što bi Rimljani zaposjeli novo područje, prisilnim iseljavanjem autohtonoga stanovništva kroz ropstvo i regrutaciju, a kasnije, kad bi se stanje stabiliziralo, i dobrovoljnim, odnosno slobodnim protokom stanovništva, emigracijama i imigracijama. Ovi potonji procesi nisu bili tako dramatični kao prvo spomenuti, no zacijelo su i oni bili vrlo dinamični i stubokom su mijenjali društva i kulturu antičkih zajednica na obali istočnoga Jadrana.

Prijevod / Translation

Domagoj Bužanić, Mirna Vukov

Lektura / Proofreading

Marko Maras established cities and markets, interfered little in the life of the local population, so it was able to remain largely outside the transforming influences on culture and social life that came with the settlers. The way in which the Romans dominated space was quite different, it implied complete, total domination over the peoples whose territories they occupied, thus causing tectonic economic and cultural changes. All these processes were strongly marked by human migrations. On the one hand, these occurred after the Romans occupied the new area, by forcible emigration of the indigenous population through slavery and recruitment, and later, when the situation stabilized, by the voluntary or free flow of population, emigration and immigration. These latter processes were not as dramatic as the first mentioned, but they were certainly also very dynamic and radically changed the societies and culture of the ancient communities on the shores of the eastern Adriatic. 


\section{KRATICE / ABBREVIATIONS}

CIL - Corpus Incriptionum Latinarum, Berlin (https://cil.bbaw.de/).

EDCS - Epigraphische Datenbank Clauss-Slaby (Manfred Clauss; http://db.edcs.eu/epigr/epi_de.php).

HD - Epigraphische Datenbank Heidelberg (Heidelberger Akademie der Wissenschaften; http://edh-www.adw.uni-heidelberg.de/ home).

ILS - Inscriptiones Latinae selectae, Berlin.

ILJug 1-451 - Šašel, A., Šašel J. 1963, Inscriptiones latinae quae in lugoslavia inter annos MCMXL et MCMLX repertae et editae sunt, Situla 5, Ljubljana.

ILJug 1223-3128 - Šašel, A., Šašel J. 1986, Inscriptiones Latinae quae in lugoslavia inter annos MCMIl et MCMXL repertae et editae sunt, Situla 25, Ljubljana.

\section{LITERATURA / BIBLIOGRAPHY}

Alföldy, G. 1962a, Municipes Tibériens et Claudiens en Liburnie, Epigraphica, Vol. 23, 53-65.

Alföldy, G. 1962b, Caesarische und augusteische Kolonien in der Provinz Dalmatiens, Acta Antiqua Hungarica, Vol. 10, 357-365.

Alföldy, G. 1969, Die Personennamen in der römischen Provinz Dalmatia, Carl Winter Universitätsverlag, Heildelberg.

Batović, Š. 1976, Le relazioni culturali tra le sponde Adriatiche nell'età del ferro, in: Jadranska obala u protohistoriji. Kulturni i etnički problemi, Simpozij održan u Dubrovniku od 19. do 23.10.1972., Suić M. (ed.), Centar za povijesne znanosti sveučilišta u Zagrebu, Arheološki institut, Zagreb, 11-93.

Bengston, H. 2002, Griechische Geschichte. Von den Anfängen bis in die römische Kaiserzeit ( $9^{\text {th }}$ ed.), C.H. Beck, München.

Bertol, A. 2014, Individual finds or a coin hoard: analysis of the Mazintype material from the Sveta Trojica hill-fort site near Starigrad Paklenica, in: Miscellanea historiae antiquitatistica, Proceedings of the First Croatian-Hungarian PhD Conference on Ancient History, Németh G., Bajnok D. (eds.), Hungarian Polis Studies 21, Eötvös Loránd University, University of Debrecen, Budapest - Debrecen, 111-142.

Bilić Dujmušić, S. 2001, Ratne operacije u provinciji Ilirik, 49. - 47. pr. Kr., Unpublished Master thesis, University of Zagreb, Zagreb.

Bilić Dujmušić, S. 2004, Oktavijanova kampanja protiv Delmata 34. - 33. god. pr. Kr., Unpublished PhD thesis, University of Zadar, Zadar

Le Bohec, Y. 1993, Die römische Armee: von Augustus zu Konstantin dem Goßen, Franz Steiner Verlag, Stuttgart.

Broadhead, W. 2001, Rome's migration policy and the so-called ius migrandi, Cahiers du Centre Gustave Glotz, Vol. 12, 69-89.

Brunšmid, J. 1898, Die Inschriften und Münzen der griechischen Städte Dalmatiens, Alfred Hödler, Wien.

Cambi, N., Čače, S., Kirigin, B. (eds.) 2002, Grčki utjecaj na istočnoj obali Jadrana, Zbornik radova sa znanstvenog skupa održanog 24. do 26. rujna 1998. godine u Splitu, Književni krug, Split.

Castignani, H. 2012, L'impérialisme défensif existe-t-il? Sur la théorie romaine de la guerre juste et sa postérité, Raisons politiques, Vol. 45(1), 35-57.

Čače, S. 1979, Prilozi proučavanju političkog uređenja naroda sjeverozapadnog Ilirika, Radovi Filozofskog Fakulteta u Zadru, Vol. 18, 43-125.

Čače, S., Milivojević, F. 2017, Rimski Ilirik u 1. st. pr. Kr.: nekoliko zapažanja, Vjesnik za arheologiju i historiju dalmatinsku, Vol. 110(2), 425-450.

Demicheli, D. 2012, Dalmatinci u Rimskome Carstvu izvan matične provincije prema epigrafičkim spomenicima, Unpublished PhD thesis, University of Zagreb, Zagreb.

Derow, P. S. 1979, Polybios, Rome and the East, The Journal of Roman Studies, Vol. 69, 1-15.

Docter, R., Boussoffara, R., Keurs, P. (eds.) 2015, Carthage: fact and myth, Sidestone Press, Leiden.

Džino, D., Domić Kunić, A. 2013, Rimski ratovi u lliriku. Povijesni antinarativ, Školska knjiga, Zagreb.

Eck W. (ed.) 1999, Lokale Autonomie und römische Ordnungsmacht in den kaiserzeitlichen Provinzen vom 1. bis 3. Jahrhundert, Schriften des Historischen Kollegs, Kolloquien 42, R. Oldenbourg Verlag, München.

\section{IZVORI / SOURCES}

Büttner Wobst, Th. (ed.) 1904, Polybius, Historiae, Teubner, Lipsiae.

C. Iulius Caesaris, De bello Alexandrino - https://penelope.uchicago. edu/Thayer/L/Roman/Texts/Caesar/Alexandrian_War/C*.html (14.07.2020.)

Strabo, Гєшүрачıкá / Geography, Loeb Classical Library, Vol. 3 (Books 6-7), The Loeb Classical Library 182, Harvard University Press, 1924.

M. Valerivs Martialis, Epigrammaton Ibri - The Latin Library, http://www.thelatinlibrary.com/martial.html (14.07.2020.)

loannis Zonaras, Epitome Historion, in: Page, T. E., Rouse, W. H. D. (eds.) 1914, Dio's Roman History, Vol. Il: Books 12-35, The Loeb Classical Library 37, William Heinemann - Macmillan co., London - New York.

Gabričević, B. 1970, Issa i njezin patron Q. Numerius Rufus, in: Adriatica praehistorica et antiqua: zbornik radova posvećen Grgi Novaku, Mirosavljević V., Rendić-Miočević D., Suić M. (eds.), Arheološki institut Filozofskog fakulteta, Zagreb, 553-562.

Gibbon, E. 1836, The History of the Decline and Fall of the Roman Empire Harper \& Brothers, New York.

Giunio, K. A. 2013, Kolegij sevira Julijala i začeci carskog kulta u rimskom Zadru (lader), Archaeologia Adriatica, Vol, 7, 199-219.

Glavičić, M. 2008, Epigrafska baština rimskodobnog Epidaura, Archaeologia Adriatica, Vol. 2(1), 43-62.

Heftner, H. 1997, Der Aufstieg Roms: Vom Pyrrhoskrieg bis zum Fall von Karthago (280-146 v. Chr.), Verlag Friedrich Pustet, Regensburg.

Hingley, R. 1996, The 'legacy' of Rome: the rise, decline, and fall of the theory of Romanization, in: Roman Imperialism: post-colonial perspectives, Webster J., Cooper N. (eds.), Leicester Archaeology Monographs 3, School of Archaeological Studies, University of Leicester, Leicester, 35-48.

Hingley, R. 2005, Globalizing Roman culture: unity, diversity and empire, Routledge, London.

Holleaux, M. 1921, Rome, la Grèce et les Monarchies hellénistiques au III siècle avant J.-C. (273-205), Bibliothèque des Écoles françaises d'Athènes et de Rome 124, Paris.

Jähne, A. 2003, Theodor Mommsen. Seine "Römische Geschichte" Sitzungsberichte der Leibniz-Sozietät, Vol. 59(3), 89-108.

Young, R. J. C. 2003, Postcolonialism: A Very Short Introduction, Oxford University Press, Oxford.

Kiely, R. 2010, Rethinking Imperialism, Palgrave Macmillan, Basinsgtoke.

Knapp, R. 2012, Römer im Schatten der Geschichte. Gladiatoren, Prostituierte, Soldaten: Männer und Frauen im Römischen Reich, Klett-Cotta Stuttgart.

Kornemann, E. 1891, De civibus Romanis in provinciis imperii consistentibus. Dissertatio inauguralis historica, Typis Expressit Martinus Oldenburg, Berlin.

Kraft, K. 1951, Zur Rekrutierung der Alen und Kohorten an Rhein und Donau, Francke Verlag, Bern.

Križman, M. 1991, Rimska imena u Istri, Latina et Graeca, Zagreb.

Lazius, W. 1557, De gentium aliquot migrationibus, sedibus fixis, reliquiis, linguarumque initiis et immutationibus ac dialectis, Libri XII, J. Oporinum, Basel.

de Ligt, L., Tacoma, L. E. 2016, Approaching Migration in the Early Roman Empire, in: Migration and Mobility in the Early Roman Empire, de Ligt L., Tacoma L. E. (eds.), Studies in Global Social History 23, Brill, Leiden, 1-22.

Linderski, J. 1984, Si vis pacem, para bellum: Concepts of Defensive Imperialism: A Theoretical Overview, in: The Imperialism of Mid-Republican Rome, Harris W. V. (ed.), Papers and Monographs of the American Academy in Rome 29, American Academy, Rome, 133-164.

Markoe, G. E. 2000, Peoples of the Past: Phoenicians, University of California Press, Berkeley.

Matica, B. (ed.) 2008, Hrvatski arheološki godišnjak 4/2007, Ministarstvo kulture $\mathrm{RH}$, Zagreb.

Mattingly, D. J. 2011, Imperialism, Power, and Identity: Experiencing the Roman Empire, Princeton University Press, Princeton - Oxford.

Mayer, M. 2004, La sociedad de la Narona romana (Vid, Metkovic, Croa- 
cia). Algunas observaciones, in: Dall'Adriatico al Danubio: L'Illirico nell'età greca e romana, Atti del convegno internazionale Cividale del Friuli, 25-27 settembre 2003, Urso G. (ed.), Edizioni ETS, Pisa, 229-246.

Mesić, J. (ed.) 2005, Hrvatski arheološki godišnjak 1/2004, Ministarstvo kulture $\mathrm{RH}$, Zagreb.

Mesić, J. (ed.) 2006, Hrvatski arheološki godišnjak 2/2005, Ministarstvo kulture $\mathrm{RH}$, Zagreb.

Mesić, J. (ed.) 2007, Hrvatski arheološki godišnjak 3/2006, Ministarstvo kulture $\mathrm{RH}$, Zagreb.

Mesić, J. (ed.) 2009, Hrvatski arheološki godišnjak 5/2008, Ministarstvo kulture $\mathrm{RH}$, Zagreb.

Mihovilić, K., Haensel, B., Teržan, B. 2005, Moncodogno. Scavi recenti e prospettive future, in: Carlo Marchesetti e i castellieri 1903-2003, Atti del Convegno Internazionale di studi, Castello di Duino (Trieste), 14-15 novembre 2003, Bandelli G., Kokelj Montagnari E. (eds.), Fonti e studi per la storia della Venezia Giulia 2, Editreg SRL, Trieste, 389-408.

Milićević Bradač, M. 2004, Stara Grčka. Grci na Crnom moru, Školska knjiga, Zagreb.

Milivojević, F. 2011, Rimski i italski poduzetnici i doseljenici u lliriku od ilirskih ratova do Cezara, Pro Tempore, Vol. 8-9/2010-2011, 188-210.

Milivojević, F. 2017, Cezarov Ilirik, Unpublished PhD thesis, University of Zadar, Zadar.

Millard, F. 1984, The Political Character of the Classical Roman Republic, 200-151 B.C., The Journal od Roman Studies, Vol. 74, 1-19. doi: https://doi.org/10.2307/299003

Millett, M. 1999, The Romanization of Britain. An Essay in Archaeological Interpretation, Camebridge University Press, Cambridge.

Miše, M. 2012, Trgovački kontakti dvaju jadranskih obala krajem 4. i u 3. st. pr. Kr. na primjeru slikane keramike, Histria Antiqua, Vol. 21, 231-240.

Mommsen, T. 1856, Römische Geschichte, Weidmannsche Buchhandlung, Berlin.

Morgenthau, H. J. 1948, Politics Among Nations: the Struggle for Power and Peace, A. A. Knopf, New York.

Mrozewicz, L. 2014, Flavian municipal foundations in Dalmatia, in: Within the Circle of Ancient Ideas and Virtues. Studies in Honour of Professor Maria Dzielska, Twardowska K., Salamon M., Sprawski S., Stachura M., Turlej S. (eds.), Historia lagellonica, Towarzystwo Wydawnicze, Krakow, 209-218.

Nölke, P. (ed.) 2004, Romanisation und Resistenz, Philipp von Zabern, Mainz am Rhein.

Piso, J. (ed.) 2008, Die römischen Provinzen: Begriff und Gründung, Editura Mega, Cluj - Napoca.

Pohl, H. 1993, Die römische Politik und die Piraterie im östlichen Mittelmeer vom 3. bis zum 1. Jh. v. Chr., Unterschungen zur antiken Literatur und Geschichte 42, De Gruyter, Berlin - New York.

Radić, D., Borzić, I., Eterović Borzić, A. 2017, Katalog, in: Grad mrtvih nad poljem života. Nekropola gradinskog naselja Kopila na otoku Korčuli, Fadić I., Eterović Borzić A. (eds.), katalog izložbe, Muzej antičkog stakla, Zadar, 148-203.

Roselaar, S. T. 2016, State-Organised Mobility in the Roman Empire: Legionaries and Auxiliaries, in: Migration and Mobility in the Early Roman Empire, de Ligt L., Tacoma L. E. (eds.), Brill, Leiden, 138-157.

Said, E. W. 1978, Orientalism, Routledge \& Kegan Paul, London.

Sanader, M. 2005, Die Griechen am ostadriatischen Festland und der vorgelagerten Inselwelt, in: Vis Imaginum. Festrchrift für Elisabeth Walde zum 65. Geburtstag, Grabherr G., Kainrath B., Larcher A., Welte B. (eds.), Institut für Klassische und Provinzialrömische Archäologie der Universität Innsbruck, Innsbruck, 413-421.

Sanader, M. 2008, O rimskom Carstvu, njegovim granicama i hrvatskom dijelu limesa, in: M. Sanader, Imago provinciarum, Alfa d.d., Zagreb, 61-77.

Sanader, M. 2018, Prilog proučavanju utjecaja rimske urbanizacije na okoliš istočne obale Jadrana, in: M. Sanader, Rimljani između Mediterana i Dunava. Odabrani radovi iz antičke provincijalne arheologije, FF press, Arheološki zavod, Zagreb, 9-15.

Sanader, M. 2020, Wirtschaftspotential der römischen Legionare. Überlegungen zu den Kleinfunden aus dem römischen Lager Tilurium, in: Das römische Heer - Wirtschaftsfaktor und Kulturträger, Colloquium Lauriacum 2016, Beiträge zur Tagung im Museum Lauriacum Enns, 22.-24. September 2016, Traxler S., Lang F. (eds.), Forschungen in Lauriacum 19, Gesellschaft für Landeskunde und Denkmalpflege Oberösterreich, Linz, 149-157.

Sanader, M., Žunec, O., Begić, N. 2007, Ratni veterani u starom Rimu i u današnjoj Hrvatskoj, Polemos, Vol. X(20), 11-30.

Sanader, M., Vukov, M., Bužanić, D. 2019, Pax Romana između Burna i Tilurija. Krajolik sukoba? / Pax Romana between Burnum and Tilurium. Landscape of conflicts?, Prilozi Instituta za arheologiju u Zagrebu, Vol. 36, 121-134. https://doi.org/10.33254/piaz.36.4

Schörner, G. 2005, Einführung, in: Romanisierung-Romanisation: Theoretische Modelle und praktische Fallbeispiele, Schörner G. (ed.), British Archaeological Reports IS 1427, BAR Publishing, Oxford, V-XVI.

Silver, M. 2016, The Role of Slave Markets in Migration from the Near East to Rome, Klio, Vol. 98(1), 184-202. https://doi.org/10.1515/ klio-2016-0006

Starac, A. 2000, Rimsko vladanje u Histriji i Liburniji II. Društveno i pravno uređenje prema literarnoj, natpisnoj i arheološkoj građi. Liburnija, Arheološki muzej Istre, Pula.

Stier, E. 1957, Roms Aufstieg zur Weltmacht und die griechische Welt, Westdeutscher Verlag, Köln - Opladen.

Suić, M. 1953, Prilog poznavanju odnosa Liburnije i Picenuma u starije željezno doba, Vjesnik za arheologiju i historiju dalmatinsku, Vol. 55, 71-101.

Suić, M. 1981, Zadar u starom vijeku, Filozofski fakultet, Zadar.

Škegro, A. 1999, Gospodarstvo rimske provincije Dalmacije, Sveučilište u Zagrebu, Hrvatski studiji, Zagreb.

Thrift, N. 2018, Afterword: Fings ain't wot they used t'be: Thinking trought material thinking as placing and arrangement, in: The Oxford Handbook of Material Culture Studies, Hicks D., Beaudry M. C. (eds.), Oxford University Press, Oxford, 634-645. doi: 10.1093/oxfordhb/9780199218714.013.0028

Vittinghoff, F. 1951, Römische Kolonisation und Bürgerrechtspolitik unter Caesar und Augustus, Verlag der Akademie der Wissenschaften und der Literatur, Mainz.

Vittinghoff, F. 1977, Zur römischen Municipalisierung des lateinischen Donau-Balkanraumes. Metodische Bemerkungen, in: Politische Geschichte (Provinzen und Randvölker: Lateinischer Donau-Balkanraum), Temporini H. (ed.), Aufstieg und Niedergang der römischen Welt II/6, De Gruyter, Berlin - New York, 3-51.

Vukov, M. 2018, Između tradicije i modifikacije. Rimski zavjetni žrtvenici u Hrvatskoj kao pokazatelji razvoja gospodarstva i društva u provincijama, Unpublished PhD thesis, University of Zagreb, Zagreb.

Walbank, F. W. 1963, Polybius and Rome's Eastern Policy, Journal of Roman Studies, Vol. 53(1-2), 1-13. https://doi.org/10.2307/298359

Wheeler, E. 2010, Rome's Dacian Wars: Domitian, Trajan, and Strategy on the Danube I, Journal of Military History, Vol. 74(4), 1185-1227.

Wheeler, E. 2011, Rome's Dacian Wars: Domitian, Trajan, and Strategy on the Danube II, Journal of Military History, Vol. 75(1), 191-219.

Werner, R. 1972, Das Problem des Imperialismus und die römische Ostpolitik im zweiten Jahrhundert v. Chr., in: Politische Geschichte, Temporini H. (ed.), Aufstieg und Niedergang der römischen Welt I/1, De Gruyter, Berlin - New York, 501-563.

Wiewegh, Z. (ed.) 2010, Hrvatski arheološki godišnjak 6/2009, Ministarstvo kulture $\mathrm{RH}$, Zagreb.

Wiewegh, Z. (ed.) 2011, Hrvatski arheološki godišnjak 7/2010, Ministarstvo kulture $\mathrm{RH}$, Zagreb.

Wiewegh, Z. (ed.) 2012, Hrvatski arheološki godišnjak 8/2011, Ministarstvo kulture $\mathrm{RH}$, Zagreb.

Wiewegh, Z. (ed.) 2013, Hrvatski arheološki godišnjak 9/2012, Ministarstvo kulture $\mathrm{RH}$, Zagreb.

Wiewegh, Z. (ed.) 2014, Hrvatski arheološki godišnjak 10/2013, Ministarstvo kulture $\mathrm{RH}$, Zagreb.

Wiewegh, Z. (ed.) 2015, Hrvatski arheološki godišnjak 11/2014, Ministarstvo kulture $\mathrm{RH}$, Zagreb.

Wilson, A. J. N. 1966, Emigration from Italy in the Republican Age of Rome, Manchester University Press, Barnes \& Noble, Manchester - New York.

Woolf, G. 1998, Becoming Roman: the origins of provincial civilization in Gaul, Camebridge University Press, Cambridge. https://doi. org/10.1017/CBO9780511518614

Zaninović, M. 1999, Rimska vojska u razvitku antike na našoj obali, in: M. Zaninović, Od Helena do Hrvata, Zagreb, 209-222.

Zaninović, M. 2015, Ilirski ratovi, Školska knjiga, Zagreb. 
